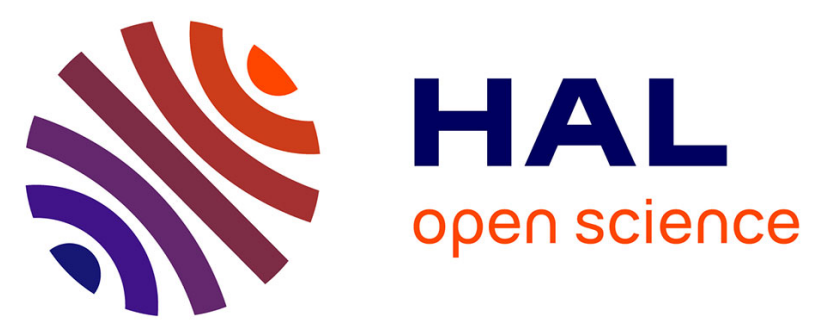

\title{
Integrated multi-trophic aquaculture of red drum (Sciaenops ocellatus) and sea cucumber (Holothuria scabra): Assessing bioremediation and life-cycle impacts
}

Killian Chary, Joël Aubin, Bastien Sadoul, A. Fiandrino, D. Covès, M. D. Callier

\section{To cite this version:}

Killian Chary, Joël Aubin, Bastien Sadoul, A. Fiandrino, D. Covès, et al.. Integrated multi-trophic aquaculture of red drum (Sciaenops ocellatus) and sea cucumber (Holothuria scabra): Assessing bioremediation and life-cycle impacts. Aquaculture, 2020, 516, pp.1-17. 10.1016/j.aquaculture.2019.734621 . hal-02437650

\section{HAL Id: hal-02437650 \\ https://hal.science/hal-02437650}

Submitted on 21 Dec 2021

HAL is a multi-disciplinary open access archive for the deposit and dissemination of scientific research documents, whether they are published or not. The documents may come from teaching and research institutions in France or abroad, or from public or private research centers.
L'archive ouverte pluridisciplinaire HAL, est destinée au dépôt et à la diffusion de documents scientifiques de niveau recherche, publiés ou non, émanant des établissements d'enseignement et de recherche français ou étrangers, des laboratoires publics ou privés.

\section{(c) (1) $\$$}

Distributed under a Creative Commons Attribution - NonCommerciall 4.0 International 
1 Integrated multi-trophic aquaculture of red drum (Sciaenops ocellatus) and sea cucumber (Holothuria 2 scabra): assessing bioremediation and life-cycle impacts

3 Killian Chary ${ }^{a^{*},}$ Joël Aubin $^{\mathrm{b}}$, Bastien Sadoul $^{\mathrm{c}}$, Annie Fiandrino $^{\mathrm{d}}$, Denis Covès ${ }^{\mathrm{a}}$, Myriam D. Callier $^{\mathrm{a}}$

4

$5 \quad{ }^{a}$ MARBEC, Ifremer, IRD, Univ. Montpellier, CNRS, Palavas-les-Flots, France

6 bUMR SAS, INRA, AGROCAMPUS OUEST, Rennes, France

$7 \quad$ 'UR1037 Fish physiology and Genomics, INRA, Rennes, France

$8 \quad$ MARBEC, Ifremer, IRD, Univ. Montpellier, CNRS, Sète, France

\section{Declarations of interest: none}

\section{Abstract}

Environmental sustainability of aquaculture is a complex issue involving effects at local (e.g. benthic

deterioration), regional (e.g. eutrophication) and global (e.g. catches for feed production) scales as a consequence of farming operations (e.g. waste emissions) and industrial processes involved in the product value chain. Integrating these effects using a holistic and multi-scale framework is essential to assess the environmental sustainability of

17 innovative production systems such as Integrated Multi-Trophic Aquaculture (IMTA), in which organisms of different

\footnotetext{
* Corresponding author.

Ifremer, Station expérimentale de Palavas, Chemin de Maguelone, 34250 Palavas-les-Flots, France.

Tel.: +33467130408.

E-mail address: Killian.Chary@ifremer.fr or Killian.Chary@gmail.com
}
Abbreviations:
AC: Acidification
CC: Climate change
CED: Cumulative energy demand
DEB: Dynamic energy budget
EU: Eutrophication
FCR: Feed conversion ratio
FU: Functional unit
IFF: Ingested fish feces
IMTA: Integrated multi-trophic aquaculture
LCA: Life cycle assessment
LCI: Life cycle inventory
LCIA: Life cycle impact assessment
LU: Land use
$\mathrm{N}$ and P: Nitrogen and Phosphorus
NPPU: Net primary production use
ThOD: Theoretical oxygen demand
UFF: Undigested finfish feces 
trophic levels are co-cultured on the same farm to minimize aquaculture waste. The environmental performances of theoretical production scenarios of red drum (Sciaenops ocellatus) sea cage monoculture and an open-water IMTA coculturing of red drum and sea cucumber (Holothuria scabra) were assessed with mathematical models at local and

21 global scales. First, the particulate waste bioremediation potential of sea cucumber production was estimated using an

22 individual-based bioenergetic model. Second, environmental impacts of the monoculture and the IMTA systems were 23 estimated and compared using life cycle assessment (LCA), calculated per kg of edible protein and t of product,

24 including uncertainty analysis. Given the current limits to stocking density observed for sea cucumbers, its co-culture 25 in sea cages suspended beneath finfish nets may decrease slightly (by $0.73 \%$ ) farm net particulate waste load and 26 benthic impact. The monoculture and IMTA showed little difference in impact because of the large difference in 27 production scales of finfish and sea cucumber species. Removing $100 \%$ of finfish feces particulate waste requires 28 cultivating sea cucumber at scale similar to that of finfish ( $1.3 \mathrm{~kg}$ of sea cucumber per $\mathrm{kg}$ of finfish). Nonetheless, 29 LCA showed trends in IMTA performance: lower eutrophication impact and net primary production use but higher 30 cumulative energy demand and climate change impacts, generating an impact transfer between categories.

31 Intensification of sea cucumber culture could increase local and global environmental benefits, but further research is 32 necessary to design rearing units that can optimize production and/or bioremediation and that can be practically 33 integrated into existing finfish monoculture units. The methodology defined here can be a powerful tool to predict the 34 magnitude of environmental benefits that can be expected from new and complex production systems and to show 35 potential impact transfer between spatial scales. We recommend applying it to other IMTA systems and species 36 associations and including socio-economic criteria to fully assess the sustainability of future seafood production 37 systems.

39 Keywords: Integrated Multi-Trophic Aquaculture (IMTA); Life cycle assessment (LCA); Bioremediation; Culture 40 scenario; Sea cucumber 


\section{Introduction}

Environmental sustainability of aquaculture is a complex and multi-scale issue involving both direct and indirect interactions with the environment (Edwards, 2015). Among the main concerns regarding sustainability of the sector, one can cite its dependence on wild-caught resources and agricultural products for the production of formulated feed, use of natural resources, discharge of chemical contaminants (e.g. medicines, heavy metals), conversion of sensitive areas (e.g. mangroves and wetlands), parasite and disease transfer between farmed and wild species, benthos deterioration and water body eutrophication (Hargrave, 2005; Holmer et al., 2008). From these examples, we can distinguish environmental impacts that are directly related to farm operations (e.g. benthic impact, water eutrophication) and that generally affect the environment at local (farm vicinity) or regional scales (bay, watershed) from those that can be indirectly caused by the successive industrial processes involved in the product value chain (e.g. catches for feed production). Exploring these interactions within a holistic framework is essential to properly address aquaculture sustainability issues and to develop new solutions for minimizing impacts on the environment.

Integrated multi-trophic aquaculture (IMTA) is perceived to be a suitable approach to decrease negative effects of aquaculture waste (Neori et al., 2004; Troell et al., 2003). The main principle of IMTA is to co-culture organisms from different trophic levels, including fed species (e.g. finfish or shrimp) and extractive species that can feed on the solid organic (e.g. bivalves, sea cucumbers, sea urchins) and dissolved inorganic (e.g. macroalgae) waste generated by the fed species. The biomitigation service thus depends on the choice of the extractive organisms, the trophic niche targeted and the associated extractive feeding behavior (e.g. filter feeding, deposit feeding, autotrophic) and its ecological functions.

IMTA can provide both environmental and socio-economic benefits by converting excess nutrients into commercial products. In an open-water IMTA, Reid et al. (2013) estimated that 2.3-4.4 kg of dissolved nitrogen (N) could be removed per kg of kelps (Alaria esculenta and Saccharina latissima) co-cultured in the proximity of Atlantic salmon (Salmo salar) cages. While other aquaculture waste management methods have involved mainly high technology and large operating costs (e.g. water filtering, sediment pumping) (Buschmann et al., 2008), IMTA is a practical bioremediation approach that offers the possibility to generate additional farm revenue (Troell et al., 2009), given that the added species has a market value. A recent study compared the financial performance of an Atlantic salmon monoculture and an IMTA system adding blue mussel (Mytilus edulis) and sugar kelp (Saccharina latissima) and showed that the IMTA operation was more profitable, with a net present value (NPV) 5.7-38.6\% higher (Carras et al., 2019). Additionally, IMTA may also decrease farm economic risk through product diversification, increase the social acceptability of aquaculture due to its better environmental image and may provide differentiation pathways 
through labeling programs (Alexander et al., 2016; Barrington et al., 2009; Chopin et al., 2012). For example,

74 Barrington et al. (2010) have demonstrated in a survey work, that participants perceived seafood produced in IMTA

75 systems as safe products to eat and showed that $50 \%$ of them were willing to pay $10 \%$ more for these products if

76 labelled as such.

77

Sea cucumbers (class Holothuroidea) are an interesting candidate as deposit feeder species for IMTA systems due to their ability to consume particulate waste excreted by other cultured organisms (Slater and Carton, 2009;

Yokoyama, 2013). This is particularly relevant for fed finfish open-water aquaculture systems, for which reducing the benthic impact is a major ecological challenge (Strain and Hargrave, 2005). The most concentrated sources of nutrients generated by finfish production systems are released as large organic particles (Filgueira et al., 2017), including finfish feces and uneaten finfish feed. Accumulation of this waste on the seabed depends on multiple factors such as farm arrangement (cage layout), production scale (Borja et al., 2009; Giles, 2008), physical characteristics of particles (settling velocity) (Magill et al., 2006; Reid et al., 2009) and hydrodynamics (currents and bathymetry) (Borja et al., 2009; Bravo and Grant, 2018; Keeley et al., 2013). High rates of deposition of organic matter on the sediment can cause organic enrichment, change sediment geochemistry and change benthic community structure near finfish cages (Borja et al., 2009; Karakassis, 2000; Pearson and Rosenberg, 1977). The co-culture of deposit-feeding organisms such as sea cucumber, which can process enriched benthic sediments, thus assimilating bacterial, fungal and detrital organic matter, seems a suitable approach to decrease nutrient enrichment in the sediment and respect the carrying capacity of the ecosystem.

Experimental studies have demonstrated sea cucumbers' ability to consume and assimilate aquaculture waste and to reduce its organic and nutrient content, confirming its potential for bioremediation in IMTA (MacDonald et al., 2013; Nelson et al., 2012; Robinson et al., 2019). Previous pilot-scale open water experiments showed overall good growth and survival of sea cucumbers cultured in suspended cages or benthic bottom culture beneath finfish cages under adequate management (Hannah et al., 2013; Yokoyama, 2013; Yokoyama et al., 2013; Yu et al., 2014, 2012), although serious mortality episodes were observed in benthic cultures due to anoxia in the sediment (Yu et al., 2012).

$$
\text { Previous studies using mathematical models to examine uptake of solid organic matter or nutrients by sea }
$$
cucumber species in IMTA systems with finfish resulted in contrasting conclusions (Cubillo et al., 2016; J. S. Ren et al., 2012; Watanabe et al., 2015; Zhang and Kitazawa, 2016). According to MacDonald et al. (2013), three to four Holothuria forskali (ca. 400-500 $\mathrm{g} \mathrm{m}^{-2}$ ) would process all solid waste produced by a commercial seabass (Dicentrachus labrax) sea-cage production unit. However, the authors assumed a mean solid deposition rate of $8.67 \mathrm{~g}$ $\mathrm{m}^{-2} \mathrm{yr}^{-1}$ citing Magill et al. (2006), while the latter authors actually reported a mean flux under the cage layout of 
5000-12 $000 \mathrm{~g} \mathrm{~m}^{-2} \mathrm{yr}^{-1}$. Model simulations by Cubillo et al. (2016) and Ren et al. (2012) predicted that bottom culture of sea cucumbers could remove more than $70 \%$ of the benthic particulate organic carbon (C) from Atlantic salmon (Salmo salar) farm units. These two studies were mainly exploratory, aiming to maximize production and optimize species combinations to reduce environmental impacts, ignoring technological and rearing constraints for the extractive species. Including such considerations in models can help predict more realistic production design and bioremediation potentials from extractive species and thus better scale and design future IMTA systems. In contrast, Watanabe et al. (2015), who calculated that $4.3 \%$ of total particulate nitrogen from milkfish (Chanos chanos) culture could be removed by detritivore species, concluded that sea cucumber may not be an effective bioremediator, since an impractical stocking density (ca. 200 times current practices) would be necessary to completely remove particulate $\mathrm{N}$. Overall, two main points limit the ability to compare results of studies. First, the main differences are expected to be due to three factors: i) the sea cucumber species cultured, ii) the production ratio between the main species (i.e. finfish) and the added species (i.e. sea cucumber) and iii) the duration of production cycles. These factors drive system performances and should be clearly stated to improve understanding of system feasibility at pilot and commercial scales. Second, bioremediation potentials are often expressed in relative terms, which are by definition ratios and therefore not directly comparable, and for different fluxes (e.g. C, N, total solids) in the seabed or coming directly from the cages, depending on research objectives. Providing intermediate results and standardizing them using generic performance metrics will facilitate robust comparison of studies and help assess IMTA system performances (Reid et al., 2018).

Several indirect environmental impacts caused by producing the additional inputs associated with the added detritivore species and its integration into the finfish monoculture unit are ignored when focusing only on waste bioremediation issues. For instance, environmental impacts of juvenile production, energy use and cage construction should be included in the analysis since they may offset local benefits. To be a sustainable option, IMTA systems should perform environmentally as well as or better than monoculture, considering both direct and indirect impacts. Combined assessment of local impacts and broader global impacts with a life cycle perspective is therefore crucial to properly understand advantages of IMTA over monoculture in terms of environmental sustainability.

Life cycle assessment (LCA) is a standardized method (i.e. International Organization for Standardization (ISO) 14040) developed to assess environmental impacts of a product by compiling resource use and emissions to the environment at all stages of its life cycle. Each resource used and substance emitted is attributed to one or more impact categories and converted by characterization models into potential environmental impacts (Guinée et al., 2002). The 
LCA framework is divided into four steps: goal, scope and system definition; life cycle inventory (LCI) of resource use and emissions; environmental impact assessment and interpretation.

LCA has been extensively applied to aquaculture systems, with 65 studies and 179 aquaculture systems reviewed in a recent meta-analysis (Bohnes et al., 2018). Most studies focused on fed species of high economic value such as salmonids or shrimp (Cao et al., 2013), but a few focused on extractive species, such as two studies of sea cucumber culture (Marín et al., 2019; Wang et al., 2015). LCA has been used mostly to identify problematic stages or components of systems and to compare alternatives such as intensive vs. extensive systems, monoculture vs. polyculture and open water vs. closed recirculating systems. To date, only a few LCA studies have examined the potential of IMTA systems to mitigate aquaculture impacts (Mendoza Beltran et al., 2018; Mendoza Beltrán and Guinée, 2014). In this context, the present study examined environmental benefits and trade-offs for finfish monoculture of shifting to an open-water IMTA system co-culturing suspended sea cucumber culture beneath finfish cages, by assessing the latter's mitigation potential at local and global scales.

\section{Materials and methods}

\subsection{Goal and scope}

The main goal of this study was to compare environmental performances of red drum (Sciaenops ocellatus) sea cage monoculture to an open-water IMTA co-culturing red drum and sea cucumber (Holothuria scabra). Specifically, the objectives were (1) to estimate the net particulate removal of the sea cucumber system and its bioremediation efficiency and (2) to perform an environmental LCA of the monoculture and the IMTA system. This study was an exante analysis of aquaculture farming scenarios in the remote French island of Mayotte, Indian Ocean. The monoculture system was a $299 \mathrm{t}$ farming scenario based on existing red drum farms surveyed on Mayotte and in French Caribbean regions (Guadeloupe and Martinique). Detailed description of the red drum monoculture can be found in Chary et al. (2019). This study focused on describing the extractive sea cucumber system and its integration into the red drum monoculture. $H$. scabra was chosen for co-culture with red drum since it is the most commonly cultured tropical sea cucumber species (Robinson and Lovatelli, 2015) and one of the edible sea cucumbers with a high commercial value (Purcell et al., 2012). It is considered for aquaculture diversification on Mayotte (Cabinet Gressard consultants et al., 2013) and already cultured in the Indian Ocean (Madagascar).

The LCA was performed from the cradle to the farm gate and included multiple stages of finfish monoculture: fingerling production and transport to the farm, feed production and transport to the farm, chemical production, energy production, equipment and infrastructure production, and farm operation (Fig. 1a). Production stages were the same in 
the monoculture and IMTA systems except for juvenile sea cucumber production, which was added to the IMTA system (Fig. 1b). In the IMTA configuration considered in the present study, sea cucumber production was closely integrated into the monoculture production system (Mendoza Beltrán and Guinée, 2014), i.e. benefitted from the existing infrastructure (e.g. rope lines), equipment (e.g. boats) and operating processes, and required only a few supplementary processes. We assumed that addition of sea cucumbers did not change the productivity of the finfish farm. The IMTA system boundaries included the unchanged monoculture system (same inputs and outputs), juvenile sea cucumber production and transport to the farm and on-farm processes. Farm products from both the monoculture and IMTA were fresh ungutted aquatic products (Fig. 1b).

Life cycle impact assessment (LCIA) was expressed simultaneously per kg of edible protein in aquatic products (both finfish and sea cucumbers) (functional unit 1, $\left.F U_{1}\right)$ and per $t$ of fresh aquatic product $\left(\mathrm{FU}_{2}\right)$. This choice considered the IMTA system as a whole (i.e. no differentiation in the origin of protein or biomass). It assumed that sea cucumber production was an explicit objective of the farm, motivated by finfish waste biomitigation as well as production and revenue diversification. This approach did not require allocation of impacts between co-products as recommended in the ISO guidelines (ISO, 2006a, 2006b) and allowed comparison of farm-level environmental performances of the monoculture and IMTA systems. The primary functional unit was kg of edible protein because protein production is the main function of animal aquaculture production systems. The second functional unit ( $1 \mathrm{t}$ of product), which is commonly used, allowed for rapid comparison with other studies (Samuel-Fitwi et al., 2012). To maintain homogeneity between products (finfish sold raw and sea cucumber sold processed), and given the unchanged ranking between monoculture and IMTA in sensitivity analyses when adding supplementary life cycle stages, postharvest processes (i.e. commercialization, transport, use, disposal) were not included in the study.

\section{$<$ Insert Figure 1 around here >}

\subsection{Inventories}

The LCIs of both systems were developed and their environmental impacts were estimated using SimaPro 8.5 software and its databases (PRé Consultants, Amersfoot, Netherlands). The ecoinvent 3.0 database was used for all background data except feed ingredients, which were taken from the French EcoAlim v.1.3 database. See the Supplementary Material for detailed LCIs. 


\subsubsection{Description of the monoculture system and its animal production parameters}

The finfish monoculture system described a scenario of a semi-industrial red-drum farm with floating sea cages located on Mayotte Island, Indian Ocean (see Chary et al., 2019). In routine operations, the farm produces $299 \mathrm{t}$ of fresh finfish per year at a low stocking density $\left(\max .20 \mathrm{~kg} / \mathrm{m}^{3}\right)$. Culture cycles are 20 months long with progressive harvests from month 13. Harvested products range from portion-size to $3000 \mathrm{~g}$ per individual. No chemotherapeutants (e.g. antibiotics) are used during finfish production. Fingerlings (individual weight of $6 \mathrm{~g}$ ) are produced and transported by truck in plastic bags from a hatchery on Mayotte. Five cohorts of 34500 fingerlings $\left(950 \mathrm{~kg} \mathrm{yr}^{-1}\right) \mathrm{are}$ introduced per year. Farm cages are composed of rectangular polyethylene netting arranged in 6 units of $2500 \mathrm{~m}^{3}$ and 4 units of $500 \mathrm{~m}^{3}$, yielding a total cage area of $1372 \mathrm{~m}^{2}$. Farm productivity per cage area is therefore ca. $218 \mathrm{~kg}$ finfish $\mathrm{m}^{-2} \mathrm{yr}^{-1}$. Land-based facilities consist of one main building for finfish processing and several shipping containers used to stock feed and materials. Feed consists of commercial pressed pellets produced on La Reunion Island and imported to the farm by sea shipping. The feed-conversion ratio (FCR), i.e. the quantity of feed ( $\mathrm{kg} \mathrm{DW}$ ) needed per $\mathrm{kg}$ of animal weight gain (kg WW), was estimated as 1.91 in the farm scenario, according to the values reported for this species on tropical sea-cage farms (Falguière, 2011).

\subsubsection{Assumptions and data sources for the monoculture}

LCI data for the finfish system were obtained from data provided by a previous study (Chary et al., 2019) and surveys conducted on Mayotte and La Reunion Islands with managers of existing finfish farms, a hatchery and a feed mill company. LCI data for the finfish hatchery were collected in 2016 through surveys at Eclosia, a hatchery producing red drum fingerlings on La Reunion, since the hatchery on Mayotte closed for economic reasons. The technologies used at Eclosia and their associated yields were representative of those at the hatchery on Mayotte; therefore, we assumed that fingerlings were produced on Mayotte.

Data on farm infrastructure and equipment, energy and input consumption were obtained from finfish farm managers in 2016. We had access to the finfish farm' historical datasets, from which detailed data were obtained, allowing the variation in consumption (e.g. fuel, electricity) relative to farm production to be estimated.

Annual production data (i.e. feed inputs and finfish harvest volumes) were taken from farm simulations under routine conditions with the FINS farm-scale model (Chary et al., 2019). FINS is a simple model combining farm production and waste emission modules to simulate farm production, feed requirements and waste discharge for finfish sea-cage systems. FINS includes several submodels (e.g. individual growth model, mass balance model), which were parametrized for red drum. The edible protein content in fresh red drum biomass was set to $10.2 \%$ based 
on a filet yield of $45 \%$ and a protein content in filet of $22.6 \%$ (Falguière, 2011). Feed intake was calculated for 5 pellet types with relatively similar proximal composition ( $\sim 50 \%$ protein, $\sim 14 \%$ lipids, $16 \%$ carbohydrate, $10 \%$ fiber, $1.5 \%$ phosphorus $(\mathrm{P}))$ but differing in diameter $(2.2,3.2,4.5,6.0$ and $9.0 \mathrm{~mm})$ and ingredient mix. Data on the ingredient mix were provided by a commercial feed-mill manager in La Reunion (data not shown due to confidentiality).

\subsubsection{Sea cucumber system assumptions and data sources}

LCI data for sea cucumbers were taken from model simulations, literature reviews and expert knowledge. LCI data for the sea cucumber hatchery were collected from literature on the $H$. scabra hatchery in southwestern Madagascar (Eeckhaut et al., 2008; Lavitra et al., 2010) and from expert reports of a project for a commercial-scale hatchery on Mayotte (Cabinet Gressard consultants et al., 2013), supplemented with hatchery experience in New Caledonia (Agudo, 2006). Design of the sea cucumber rearing structure is still relatively unknown for suspended co-culture with finfish, particularly for systems at large commercial scales (Zamora et al., 2018). Therefore, data on the rearing structure were based on the current technology used at the pilot scale in previous finfish-sea cucumber IMTA studies (Hannah et al., 2013; Yokoyama, 2013). The sea cucumber rearing system consists of cylindrical cage nets (diameter 2 $\mathrm{m}$, height $40 \mathrm{~cm}$ ) suspended $\sim 3 \mathrm{~m}$ directly below the bottom of the finfish net pens and attached to the existing finfish cage mooring system with ropes (see Fig. 1b in Yokoyama 2013). Sea cucumber cages were composed of metal frames and covered with nylon mesh net. Similarly to the design used by Hannah et al. (2013) and Yokoyama (2013) we did not considered sand substrate in the cages. However, sand can be a necessary material for feeding (Robinson et al., 2013; Watanabe et al., 2012), burrowing, and wellbeing of sea cucumbers (Battaglene and Bell, 2004; Mercier et al., 1999). Due to its direct proximity to the particulate source, we assume that the sea cucumber system retains $100 \%$ of finfish feces loads and that they are homogenously available to the sea cucumbers. The areas of sea cucumber culture and the finfish farm (i.e. total bottom cage area) are identical, i.e. $1372 \mathrm{~m}^{2}$, corresponding to 437 cage units adjacent to each other. During the grow-out period, sea cucumbers are assumed to feed exclusively on finfish feces coming from the finfish cages, so no extra feed was considered. Management of sea cucumber culture consists of one cohort of individuals released in cages at a weight of $10 \mathrm{~g}$ (Battaglene et al., 1999; Lavitra et al., 2010; Purcell and Simutoga, 2008) and harvested at one time, after a 12 month culture cycle. Juvenile sea cucumbers were assumed to be produced on Mayotte and transported to the farm by truck. A single 12 month culture cycle was chosen instead of several shorter cycles in order to maximize profits, because the retail price of $H$. scabra increases exponentially with its size (Purcell, 2014; Purcell et al., 2018). Annual production and waste emissions data were estimated for sea cucumbers by integrating an individual bioenergetic model into a population dynamics framework (see section 2.2.4). 
Sea cucumbers must be processed to obtain a dry cooked commercial product called "bêche-de-mer". The processing yields from fresh animal to bêche-de-mer are assumed to be 7.5\% (Lavitra et al., 2008). The protein content in the final product is 51.2\% (Average from Ozer et al., 2004) giving an edible protein content in fresh sea cucumbers of 3.8\%. Processing stages into bêche-de-mer were not included in the LCA system boundaries.

\subsubsection{Individual bioenergetic model and population model for the sea cucumber}

The ecophysiology of sea cucumbers was simulated from seeding to harvest at a daily time step with the Dynamic Energy Budget (DEB) model (Kooijman, 2000). The model's differential equations were solved with a Runge-Kutta integration method using the deSolve (Soetaert et al., 2010) package in $\mathrm{R}$ (R Core Team, 2018). DEB models quantify the rates of energy ingestion, assimilation and use as a function of the organism, temperature and food availability (van der Meer, 2006). DEB parameters for H. scabra (version 2017/09/15) were obtained from the "Add my Pet" database (Marques et al., 2018) except for assimilation efficiency, which was calculated specifically for animals fed on finfish feces. The food availability index (f) ranges from 0-1, representing respectively an absence of food and saturated feeding (i.e. ad libitum) conditions. We set $\mathrm{f}=1$ and verified that food supply at the cohort level remained non-limiting during sea cucumber grow-out. Maintaining food availability at its maximum causes the model to predict maximum theoretical growth for the farmed animals at a given temperature. This is not likely in practice, due to the many environmental pressures affecting animals' life cycles (biology), but it allows the maximum mitigation capacity to be predicted, which accords with the goal of this study. Energy from ingested finfish feces (IFF) was converted into mass using gross energy density coefficients of red drum feces (Table A.1).

Uptake of solid particulate matter from sea cucumber ingestion and the associated solid and dissolved emissions were estimated using DEB. Sea cucumber fecal emissions (i.e. undigested finfish feces (UFF)) were estimated by DEB using an assimilation efficiency parameter $\left(\kappa_{\mathrm{X}}\right)$, which is the ratio of assimilated energy to ingested energy. In this study, we estimated $\kappa_{\mathrm{x}}$ for $H$. scabra feeding on finfish feces as $43.65 \%$ (Table A.2), since the value of $80 \%$ in the "Add my Pet" database was a default value used for a generalized animal and obtained from estimates for a wide variety of species (Kooijman, 2010). See the Appendix A for the method used to estimate $\kappa_{x}$. Dissolved emissions are derived from two distinct mechanisms in DEB. The N:P stoichiometry in the animal is assumed to remain constant over time. Assimilated nutrients that are not retained in biomass gain are therefore excreted to maintain this constant stoichiometry. Thus, $\mathrm{N}$ or $\mathrm{P}$ are excreted depending on the balance between the stoichiometry of the assimilated feed and that of the animal. The energy used for maintenance, growth and gonad formation can be translated into $\mathrm{N}-\mathrm{NH}_{4}{ }^{+}$ 
and $\mathrm{P}_{-} \mathrm{PO}_{4}{ }^{3-}$ fluxes using conversion factors. See the Appendix A for full details of the equations and parameters used in DEB to estimate dissolved emissions.

On-farm sea cucumber biomass dynamics were calculated by multiplying the number of individuals by the individual weight predicted by DEB. The population dynamics model of sea cucumber represents (i) initial seeding (initial condition), (ii) culture-harvesting strategies, (iii) natural mortality and (iv) culture losses (e.g. poaching, predation). Natural mortality and culture losses were respectively set linearly at $0.055 \% \mathrm{~d}^{-1}$ (20\% per year) and $0.014 \% \mathrm{~d}^{-1}$ (5\% per year) (Robinson and Pascal, 2011; Watanabe et al., 2015), and the harvesting rate equaled 0 , except on day 365 , when all biomass was harvested. An initial seeding density of $36 \mathrm{~g} \mathrm{~m}^{-2}$ (5000 individuals, i.e. 3.6 ind $\mathrm{m}^{-2}$ ) was calculated to achieve a maximum critical stocking density of $2000 \mathrm{~g} \mathrm{~m}^{-2}$ during the culture cycle. Since maximum stocking density is reached at the end of the culture cycle, it also corresponds to the system's productivity.

\subsubsection{Grow-out emissions from monoculture and IMTA}

There is direct interaction between finfish and sea cucumber systems in the IMTA system, since sea cucumbers are assumed to feed on finfish feces for growth and thus to retain solid nutrients that would be otherwise released into the marine environment. In this study, on-farm metabolic emissions due to finfish and sea cucumber growth focused on $\mathrm{N}$ and $\mathrm{P}$ because of their accountability in LCA impact categories such as eutrophication (EU) and their potential to cause environmental damage in aquatic environments. In this case, $\mathrm{P}$ emissions are of particular importance because they usually limit primary productivity in tropical oligotrophic environments such as the Mayotte lagoon (Howarth, 1988; Jessen et al., 2015). We also estimated theoretical oxygen demand (ThOD), i.e. the amount of oxygen required to oxidize solid organic waste, since it is also accountable in the EU impact category (Papatryphon et al., 2004). ThOD was calculated based on the chemical oxygen demand of each macronutrient (i.e. protein, carbohydrates, lipids, fiber and ash) in uneaten feed, finfish feces and sea cucumber feces (Kim et al., 2000).

In the finfish monoculture, solid organic particulate waste (i.e. uneaten feed and feces) and dissolved inorganic emissions to the sea were estimated previously for a routine year of production (Chary et al., 2019). The annual solid waste load from the red drum farm was $120454 \mathrm{~kg}$ of feces (including $2867 \mathrm{~kg} \mathrm{~N}$ and $2240 \mathrm{~kg} \mathrm{P}$ ) and $29474 \mathrm{~kg}$ of uneaten feed (including $2428 \mathrm{~kg} \mathrm{~N}$ and $383 \mathrm{~kg} \mathrm{P}$ ). Annual dissolved emissions equaled $33198 \mathrm{~kg} \mathrm{~N}-\mathrm{NH}_{4}$ and $2266 \mathrm{~kg}$ P-PO . ThOD coefficients for uneaten feed and finfish feces were respectively 1.249 and $0.854 \mathrm{~kg} \mathrm{O}$ per kg.

In the sea cucumber LCI, net $\mathrm{N}$ emissions, net $\mathrm{P}$ solid and dissolved emissions and net ThOD were calculated as solid and dissolved emissions from sea cucumber growth minus avoided emissions associated with IFF. ThOD coefficients for sea cucumber feces were estimated as $0.764 \mathrm{~kg} \mathrm{O}$ per $\mathrm{kg}$. 
On Mayotte, most economic inputs used on the farm are imported from La Reunion or France. Therefore, most processes were adapted to include sea transport (1700 km from La Reunion and $9800 \mathrm{~km}$ from France) by transoceanic ship from the closest trading ports, and land transport $(30 \mathrm{~km})$ by truck from the port to the farm facilities. Fuels were assumed to be imported from Singapore $(7000 \mathrm{~km})$.

\subsection{Environmental performance assessment}

\subsubsection{Bioremediation performances}

Bioremediation performances of sea cucumber culture were estimated using five indices (Table 1). The solid processing rate $\left(\mathrm{kg}\right.$ solid $\left.\mathrm{m}^{-2} \mathrm{yr}^{-1}\right)$ represents the ability of sea cucumbers to ingest and process fish feces in time and space. The net solid uptake rate $\left(\mathrm{kg}\right.$ solid $\left.\mathrm{m}^{-2} \mathrm{yr}^{-1}\right)$ represents the mass balance of net solids of sea cucumbers and equals IFF minus UFF. These two indices assume that finfish and sea cucumber feces have the same impact. Waste extraction efficiency (in \%) is the net reduction in solid waste (feces only) of the IMTA system compared to the annual solid waste load of finfish monoculture. The biomass culture ratio (kg:kg) (Reid et al., 2018) is the biomass of co-cultured species required to reach a waste extraction efficiency of $100 \%$ (i.e. to retain the annual solid waste load of the finfish unit in sea cucumber biomass). It is important to note that a waste extraction efficiency of $100 \%$ does not mean that the IMTA system has zero waste, since the sea cucumber culture also generates solid waste. The culture area ratio $\left(\mathrm{m}^{2}: \mathrm{m}^{2}\right)$ is the sea cucumber culture area necessary to extract $100 \%$ of feces released per unit of finfish culture area.

Table 1. Indices used to quantify bioremediation performances of sea cucumbers co-cultured with finfish in an open water integrated multitrophic aquaculture system. IFF and UFF are respectively cumulative ingested finfish feces and undigested finfish feces by the sea cucumber cohort over the 12-month culture-cycle simulation. WW and DW refer respectively to wet and dry weight.

\begin{tabular}{|c|c|c|}
\hline Index & Equation & Variable description and units \\
\hline \multirow{2}{*}{ Solid processing rate (SP) } & $I F F$ & 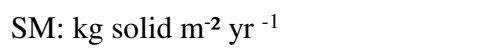 \\
\hline & $\overline{\text { Sea cucumber culture area }}$ & IFF: kg DW yr ${ }^{-1}$ \\
\hline \multirow{2}{*}{ Net solid uptake rate (NSU) } & $I F F-U F F$ & NSU: $\mathrm{kg}$ solid m $\mathrm{yr}^{-1}$ \\
\hline & $\overline{\text { Sea cucumber culture area }}$ & UFF: $\mathrm{kg} \mathrm{DW} \mathrm{yr}^{-1}$ \\
\hline \multirow[t]{2}{*}{ Waste extraction efficiency (WEE) } & & WEE: \% \\
\hline & $\overline{\text { Annual fish feces load }} \times 100$ & Annual finfish feces load: $\mathrm{kg} \mathrm{DW} \mathrm{yr}^{-1}$ \\
\hline \multirow{3}{*}{ Biomass culture ratio $(\mathrm{BC})$} & Annual fish feces load $\times$ Seacucumber nroduction & \multirow{3}{*}{ 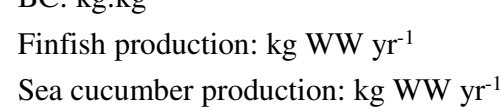 } \\
\hline & $\frac{\text { Annual Jisn Jeces load } \times \text { sea cucumber proauction }}{(I F F-U F F) \times \text { Fich }}$ & \\
\hline & & \\
\hline
\end{tabular}




$\begin{array}{ll}\text { Culture area ratio }(\mathrm{CS}) & B C \times \frac{\text { Fish cage productivity }}{\text { Sea cucumber cage productivity }}\end{array}$\begin{tabular}{l}
$\begin{array}{l}\text { Finfish cage productivity: } \mathrm{kg} \mathrm{m}^{-2} \mathrm{yr}^{-1} \\
\text { Sea cucumber cage productivity: } \\
\mathrm{kg} \mathrm{m}^{-2} \mathrm{yr}^{-1}\end{array}$ \\
\hline
\end{tabular}

\subsubsection{Life cycle impact assessment and uncertainties}

Six impact categories were selected for the LCIA: climate change potential (CC), acidification potential (AC), eutrophication potential (EU), cumulative energy demand (CED), land use (LU) and net primary production use (NPPU). These categories were chosen for their relevance to the known principal impacts of aquaculture systems and to enable comparison with previous seafood LCA studies (Bohnes and Laurent, 2019; Pelletier et al., 2007). CC (kg $\mathrm{CO}_{2}$ eq.) quantifies impact of the production of $\mathrm{GHG}$ emissions. $\mathrm{AC}$ ( $\mathrm{g} \mathrm{SO}_{2}$ eq.) represents damage to ecosystems caused by changes in the acidity of water and soil environments that receive pollutants. EU ( $\mathrm{g} \mathrm{PO}_{4}$ eq.) represents impacts on aquatic and terrestrial ecosystems due to over-enrichment in nutrients, resulting in an increase in primary and secondary production, the potential for algal blooms and oxygen depletion in the environment. CED (MJ) includes all energy resources used (e.g. fuel, heating, electricity, gas) in the system and was calculated using the Cumulative Energy Demand method v.1.09 (Frischknecht et al., 2004). LU $\left(\mathrm{m}^{2} \mathrm{y}\right)$ represents the temporary terrestrial ground area used. NPPU ( $\mathrm{kg} \mathrm{C}$ ) represents the trophic level estimated from the amount of $\mathrm{C}$ from primary production (obtained by photosynthesis) used by the cultured species. Higher NPPU means a higher trophic level. NPPU was quantified according to Papatryphon et al., (2004). For crop-based feed ingredients, NPPU was calculated according to the C content in the harvested part of the crop using its proximate composition and stoichiometric conversion factors for carbohydrate, protein and lipid fractions (Papatryphon et al., 2004). Proximate compositions of crop-based ingredients were taken from Sauvant et al. (2004). For fishery-derived feed ingredients, we used the values calculated by Papatryphon et al. (2004) for Peruvian fisheries products. CC, AP, EP, and LU were calculated according to the CML2 Baseline 2000 V2.0 method.

It is important to include uncertainty analysis in comparative LCAs, since deterministic results that do not include significance information can lead to oversimplified conclusions (Mendoza Beltran et al., 2018), especially in ex-ante analysis. Uncertainties due to unrepresentativeness (i.e. degree of reliability, completeness, temporal correlation, geographical correlation, technological correlation and sample size) of foreground processes were estimated with the Numerical Unit Spread Assessment Pedigree following the method of Henriksson et al. (2014) and included in the LCI of the monoculture and the IMTA. We simulated 1000 Monte Carlo runs to propagate these uncertainties to the LCIA results per impact category, as commonly done in LCA uncertainty analysis (Avadí and Fréon, 2013). A paired 
t-test was used to determine statistical significance of the systems' difference in environmental impacts. The null hypothesis in the t-test was that IMTA and monoculture systems have equal environmental impacts per functional unit.

\section{Results}

\subsection{Sea cucumber: model predictions at individual and system levels}

The $H$. scabra DEB model with the fixed f-value of 1 predicted that $10 \mathrm{~g}$ juveniles (length $=8 \mathrm{~cm}$ ) cultured at a water temperature of $25.2-29.6^{\circ} \mathrm{C}\left(\right.$ mean $\left.=27.8^{\circ} \mathrm{C}\right)$ with ad libitum feeding would grow into $709 \mathrm{~g}$ wet weight $(\mathrm{WW})$ (i.e. 103 g DW, $33 \mathrm{~cm}$ long) market-size individuals over 365 days. Cumulative ingestion was estimated as $879 \mathrm{~g}$, of which $671 \mathrm{~g}$ were not assimilated and egested as feces. FCR was high (8.64). Individual dissolved inorganic excretions were $10.0 \mathrm{~g}$ of $\mathrm{N}-\mathrm{NH}_{4}$ and $25.9 \mathrm{~g}$ of $\mathrm{P}_{-} \mathrm{PO}_{4}$. These individual results were extrapolated at cohort level to estimate sea cucumber biomass production and emissions in the IMTA system.

Figure 2 shows biomass and waste fluxes in the sea cucumber system and Table 2 summarizes biomass and emission outputs in the monoculture and IMTA. The number of sea cucumber decreased from 5000 to 3894 individuals, providing a potential harvest of ca. $2.8 \mathrm{t}$ (i.e. $106 \mathrm{~kg}$ of edible protein) per 12-month cycle for a culture area of $1372 \mathrm{~m}^{2}$. The addition of sea cucumber to create the IMTA increased total aquatic production by $0.92 \%$ and edible protein production by $0.34 \%$ (Table 2). Net on-farm nutrient emissions of sea cucumbers were $-30.5 \mathrm{~kg} \mathrm{~N}$ ($72.8 \mathrm{~kg}$ solid and $42.3 \mathrm{~kg}$ dissolved), $-2.8 \mathrm{~kg} \mathrm{P}$ (-38.8 $\mathrm{kg}$ solid and $36.0 \mathrm{~kg}$ dissolved).

Figure 2 also presents sea cucumber bioremediation performances when co-cultured with finfish in the IMTA system. IFF by sea cucumbers (3743 $\mathrm{kg}$ solid $\left.\mathrm{yr}^{-1}\right)$, represented $3.1 \%$ of the annual finfish feces load in monoculture $\left(120454 \mathrm{~kg}\right.$ solid $\left.\mathrm{yr}^{-1}\right)$ and a SP of $2728 \mathrm{~kg}$ solid $\mathrm{m}^{-2} \mathrm{yr}^{-1}$. When including sea cucumber fecal egestion (UFF $=2858$ $\mathrm{kg}$ solid $\mathrm{yr}^{-1}$ ), NSU was $0.645 \mathrm{~kg}$ solid $\mathrm{m}^{-2} \mathrm{yr}^{-1}$, and the WEE of the sea cucumber in IMTA was $0.73 \%$. In the IMTA system, the farm solid waste load was reduced by $885 \mathrm{~kg}$ solid $\mathrm{yr}^{-1}$ (IFF-UFF), i.e. $320.6 \mathrm{~kg}$ solid per $\mathrm{t}$ of sea cucumber produced. As a consequence, a $376 \mathrm{t}$ production of sea cucumber is necessary to extract $120454 \mathrm{~kg}$ solid $\mathrm{yr}^{-}$ 1, i.e. 1.26 times $(\mathrm{BC}=1.3: 1)$ the finfish production $\left(298.6 \mathrm{t} \mathrm{yr}^{-1}\right)$. Considering the productivity of sea cucumber $(2 \mathrm{~kg}$ $\mathrm{m}^{-2}$ cages $\mathrm{yr}^{-1}$, see section 2.2.4), this sea cucumber production requires a culture surface of ca. $187860 \mathrm{~m}^{2}$ to reach $100 \%$ extraction, i.e. 137 times the culture area of the finfish $(C S=137: 1)$. 


\begin{tabular}{llll}
\hline & Unit & Monoculture & IMTA \\
\hline Production & & & \\
Finfish production & $\mathrm{t} \mathrm{yr}^{-1}$ & 298.578 & 298.578 \\
Sea cucumber production & $\mathrm{t} \mathrm{yr}^{-1}$ & 0 & 2.761 \\
Total production & $\mathrm{t} \mathrm{yr}^{-1}$ & 298.578 & 301.339 \\
Total edible protein & $\mathrm{t} \mathrm{yr}^{-1}$ & 30.455 & 30.560 \\
& & & \\
On-farm emissions & & & \\
Finfish feces & $\mathrm{kg} \mathrm{yr}^{-1}$ & 120454 & 116711 \\
Sea cucumber feces & $\mathrm{kg} \mathrm{yr}^{-1}$ & 0 & 2858 \\
Uneaten feed & $\mathrm{kg} \mathrm{yr}^{-1}$ & 29474 & 29474 \\
Net N, solid & $\mathrm{kg} \mathrm{yr}^{-1}$ & 5295 & 5222 \\
Net N, dissolved & $\mathrm{kg} \mathrm{yr}^{-1}$ & 33198 & 33240 \\
Net P, solid & $\mathrm{kg} \mathrm{yr}^{-1}$ & 2623 & 2584 \\
Net P, dissolved & $\mathrm{kg} \mathrm{yr}^{-1}$ & 2666 & 2702 \\
Theoretical oxygen demand & $\mathrm{kg} \mathrm{yr}^{-1}$ & 139721 & 138708 \\
\hline
\end{tabular}

\subsection{LCIA results}

The monoculture and IMTA systems ranged 863-871 m²y, 9533-9599 kg C, 64 693-64967 MJ, 122.7-124.2 kg PO eq., $17.65 \mathrm{~kg} \mathrm{SO}_{2}$ eq., $2332 \mathrm{~kg} \mathrm{CO}_{2}$ eq. per t of fresh aquatic product respectively for $\mathrm{LU}, \mathrm{NPPU}, \mathrm{CED}, \mathrm{EU}, \mathrm{AC}, \mathrm{CC}$ (Fig. 3). The contribution of the production components to the monoculture and IMTA environmental impacts per kg of edible protein $\left(\mathrm{FU}_{1}\right)$ is summarized in Table 3. The same trends were observed in contributions per $\mathrm{t}$ of fresh aquatic product $\left(\mathrm{FU}_{2}\right)$ (data not shown). The contribution analysis showed few differences in the distribution of impacts between both systems. Feed production was the main contributor, with 73-99\% of the impact for all categories except EU. Animal by-products (fish meal and fish oil) contributed most to CC and NPPU, while crop-based products contributed most to AC, CED and LU. Farm operation contributed most (92\%) to EU of the monoculture and IMTA systems due to on-farm $\mathrm{N}$ and $\mathrm{P}$ emissions. In the IMTA system, net emissions from sea cucumbers reduced EU by $0.12 \%$ due to the emissions avoided by ingesting finfish feces. The ThOD from solid emissions contributed to ca. $9 \%$ of EU in both systems. Energy production was the second largest contributor (ca. 12-17\%) to CC and AC due mainly to emissions of greenhouse gases (GHGs) and other gases $\left(\mathrm{NO}_{\mathrm{x}}, \mathrm{SO}_{2}, \mathrm{NH}_{3}\right)$ from petroleum-based electricity production on Mayotte. Fingerling production and juvenile sea cucumber production contributed little $(<4 \%$ and $<$ $0.5 \%$ of total impacts, respectively), regardless of impact category. The contribution of fingerling production to CC, $\mathrm{AC}$ and CED were related mainly to energy use in the hatcheries, while its contribution to NPPU and LU were due to the feed used to maintain breeders. 
Table 3. Life cycle impact assessment results per $1 \mathrm{~kg}$ of edible protein in a red drum monoculture scenario (Mono) and in an Integrated MultiTrophic Aquaculture (IMTA) scenario co-culturing red drum and the sea cucumber $H$. scabra. Contribution to the total impact per production component is given in percentage, while mean total impact, calculated from 1000 Monte Carlo runs, is given in absolute value.

\begin{tabular}{|c|c|c|c|c|c|c|c|c|c|}
\hline Impact & $\begin{array}{l}\text { Scenari } \\
\mathrm{o}\end{array}$ & $\begin{array}{l}\text { Finfish- } \\
\text { feed } \\
\text { production }\end{array}$ & $\begin{array}{l}\text { Fingerling } \\
\text { production }\end{array}$ & $\begin{array}{l}\text { Juvenile } \\
\text { sea } \\
\text { cucumber } \\
\text { production }\end{array}$ & $\begin{array}{l}\text { Equipment } \\
\text { and } \\
\text { infrastructure }\end{array}$ & Energy & Chemicals & $\begin{array}{l}\text { Farm } \\
\text { operatio } \\
n\end{array}$ & $\begin{array}{l}\text { Mean total } \\
\text { per kg of } \\
\text { edible } \\
\text { protein }\end{array}$ \\
\hline \multirow{2}{*}{$\begin{array}{l}\text { Climate change (kg } \\
\mathrm{CO}_{2} \text { eq.) }\end{array}$} & Mono & 76.2 & 3.2 & - & 7.4 & 12.2 & 0.0 & 1.1 & 22.8 \\
\hline & IMTA & 75.4 & 3.1 & 0.3 & 8.3 & 12.1 & 0.0 & 1.1 & 23.0 \\
\hline \multirow{2}{*}{$\begin{array}{l}\text { Acidification }\left(\mathrm{g} \mathrm{SO}_{2}\right. \\
\text { eq.) }\end{array}$} & Mono & 74.2 & 3.2 & - & 5.2 & 16.6 & 0.0 & 0.9 & 173.2 \\
\hline & IMTA & 73.5 & 3.2 & 0.3 & 5.9 & 16.5 & 0.0 & 0.9 & 173.9 \\
\hline \multirow{2}{*}{$\begin{array}{l}\text { Eutrophication }\left(\mathrm{g} \mathrm{PO}_{4}\right. \\
\text { eq.) }\end{array}$} & Mono & 7.0 & 0.2 & - & 0.2 & 0.2 & 0.0 & 92.4 & 1218.5 \\
\hline & IMTA & 7.0 & 0.2 & 0.0 & 0.2 & 0.2 & 0.0 & 92.4 & 1211.2 \\
\hline \multirow{2}{*}{$\begin{array}{l}\text { Cumulative energy } \\
\text { demand (MJ) }\end{array}$} & Mono & 97.2 & 1.5 & - & 0.9 & 0.3 & 0.0 & 0.1 & 280.1 \\
\hline & IMTA & 97.1 & 1.5 & 0.0 & 1.0 & 0.3 & 0.0 & 0.1 & 278.8 \\
\hline \multirow{2}{*}{$\begin{array}{l}\text { Net primary production } \\
\text { use }(\mathrm{kg} \mathrm{C})\end{array}$} & Mono & 98.7 & 1.3 & - & 0.0 & 0.0 & 0.0 & 0.0 & 93.9 \\
\hline & IMTA & 98.7 & 1.3 & 0.0 & 0.0 & 0.0 & 0.0 & 0.0 & 93.7 \\
\hline \multirow[t]{2}{*}{ Land use $\left(\mathrm{m}^{2} \mathrm{y}\right)$} & Mono & 94.4 & 2.9 & - & 2.3 & 0.2 & 0.0 & 0.1 & 8.5 \\
\hline & IMTA & 94.3 & 2.9 & 0.3 & 2.5 & 0.2 & 0.0 & 0.1 & 8.5 \\
\hline
\end{tabular}

Overall, the uncertainties in the LCIA results were largely higher (3-9\% of the mean value, depending on impact category, Fig. 3) than the differences in impact observed between monoculture and IMTA. The IMTA system performed better than the monoculture system for EU, NPPU and LU for both functional units. Differences in impact of aquatic products per $\mathrm{kg}$ of edible protein were largest for $\mathrm{CC}$ and $\mathrm{EU}$, with a $0.8 \%$ increase and $0.6 \%$ decrease in IMTA compared to the monoculture system, respectively, while per $\mathrm{t}$ of fresh aquatic product, EU decreased by $1.2 \%$ in IMTA (Table 4). Despite the high uncertainties, LCA results differed significantly $(\mathrm{p}<0.05)$ between the two scenarios, except for LU per kg of edible protein and AC per t of fresh aquatic product.

Table 4. Life Cycle Impact Assessment results of a red drum monoculture (Mono) scenario and an Integrated Multi-Trophic Aquaculture (IMTA) scenario co-culturing red drum and the sea cucumber H. scabra, with uncertainty assessed from 1000 Monte Carlo runs. The null hypothesis in the t-test is that both systems have equal environmental impacts per functional unit.

\begin{tabular}{lllllll}
\hline \multirow{2}{*}{ Impact category } & \multicolumn{2}{c}{ Impact per kg of edible protein } & \multicolumn{2}{c}{ Impact per t of harvested product } \\
\cline { 2 - 7 } & Ranking & $\begin{array}{l}\text { Percentage } \\
\text { difference }\end{array}$ & $\begin{array}{l}\text { Paired } \\
\text { t-test }\end{array}$ & Ranking & $\begin{array}{l}\text { Percentage } \\
\text { difference }\end{array}$ & $\begin{array}{l}\text { Paired } \\
\mathrm{t} \text { test }\end{array}$ \\
\hline Climate change & IMTA > Mono & 0.8 & $\mathrm{p}<0.05$ & IMTA $>$ Mono & 0.4 & $\mathrm{p}<0.05$ \\
\hline Acidification & IMTA > Mono & 0.4 & $\mathrm{p}<0.05$ & IMTA $>$ Mono & 0.0 & $\mathrm{p}>0.05$ \\
\hline Eutrophication & Mono $>$ IMTA & 0.6 & $\mathrm{p}<0.05$ & Mono $>$ IMTA & 1.2 & $\mathrm{p}<0.05$ \\
\hline Cumulative energy demand & IMTA > Mono & 0.5 & $\mathrm{p}<0.05$ & IMTA $>$ Mono & 0.4 & $\mathrm{p}<0.05$ \\
\hline Net primary production use & Mono $>$ IMTA & 0.3 & $\mathrm{p}<0.05$ & Mono $>$ IMTA & 0.7 & $\mathrm{p}<0.05$ \\
\hline Land use & Mono $>$ IMTA & 0.5 & $\mathrm{p}>0.05$ & Mono $>$ IMTA & 0.9 & $\mathrm{p}<0.05$ \\
\hline
\end{tabular}




\section{Discussion}

We discuss the mitigation potential of the IMTA system in terms of i) the bioremediation efficiency of sea cucumber system co-cultured with finfish and ii) comparison of the impacts of the finfish monoculture and IMTA systems estimated by LCA. Perspectives are then discussed for decreasing the IMTA's benthic impact and overall lifecycle impacts.

\subsection{Sea cucumber bioremediation potential}

The first important steps to estimate the mitigation potential of organic extractive culture in an IMTA are to quantify its ingestion capacities and estimate the balance between solid uptake and particulate emissions of the extractive species. The individual annual feed energy requirement for $H$. scabra at its maximum growth potential (fvalue $=1$ in $\mathrm{DEB}$ ) was equivalent to the energy contained in $0.879 \mathrm{~kg}$ of finfish feces, which is its theoretical ingestion capacity. This ingestion rate is much lower than the range of 9-82 $\mathrm{kg}$ sediment $\mathrm{yr}^{-1}$ observed for sea cucumbers feeding in the wild (Purcell et al., 2016) because of the much higher energy content in fish feces. However, our estimates lie within the range of values obtained for sea cucumbers fed with finfish waste, i.e. about $1 \mathrm{~kg}$ solids $\mathrm{yr}^{-1}$ for Holothuria forskalli and $5 \mathrm{~kg}$ solids $\mathrm{yr}^{-1}$ for Parastichopus californicus (Cubillo et al., 2016; MacDonald et al., 2013). At the farm scale, the solid processing rate of sea cucumbers appears negligible compared to that of other organic extractive species. For instance, we back-estimated fish feces ingestion rates from mussel lines based on pseudo-feces egestion rates (maximum at $6735 \mathrm{~g} \mathrm{~m}^{-2} \mathrm{~d}^{-1}$ ), digestibility of fish feces and seston (respectively $86 \%$ and $46 \%$ ) and their respective percentage in the material ingested by the mussels (maximum $30 \%$ of fish feces, and thus $70 \%$ of seston) provided by Cranford et al. (2013). The value estimated (793 $\mathrm{kg}$ fish feces $\left.\mathrm{m}^{-2} \mathrm{yr}^{-1}\right)$ is ca. 290 times as high as that calculated for sea cucumbers (Fig. 2). When compared to the net solid uptake, however, conclusions are less straightforward. Mussels also capture suspended ambient seston (non-settling particles) and transform it into pseudo-feces (settling particles), which can lead to no gain in net organic loading (Filgueira et al., 2017). To this extent, sea cucumber showed a low but positive net solid uptake, demonstrating its interest for bioremediation.

The waste extraction efficiency of sea cucumbers was low, and expecting high removal of fish feces may be impractical at a commercial scale. In the conditions simulated, sea cucumber culture can remove $0.73 \%$ of the annual finfish farm feces load. Significant change in the production system would be necessary to reach $100 \%$ extraction, starting with more balanced production between sea cucumbers and finfish (1.3:1). In such a system, the frontier between primary and secondary species is less clear and would require large changes in the farmer's practices and skill sets, but also in the overall farm design. Given the culture area ratio (137:1) needed to reduce fish feces emissions 
to zero, the licensed surface area would have to be increased greatly because of limits to stocking density of sea cucumber culture. Stocking density has been mentioned as a limitation of IMTA systems that add sea cucumber (Purcell et al., 2012; Watanabe et al., 2015), mussels (Cranford et al., 2013) and seaweed to existing finfish monoculture for bioremediation. For seaweed, previous studies suggested that $0.07-0.28$ ha $^{-1}$ of finfish standing stock were necessary to remove all excess dissolved $\mathrm{N}$ associated with a commercial finfish farm (see Table 2 in Reid et al., 2013) because of its need to access large amounts of solar radiation at the ocean surface. For the finfish monoculture assessed here (mean $=218 \mathrm{t}$ of finfish biomass stock in routine production), it would represent a culture area ratio of 111:1 to 444:1. Thus, sea cucumber may require less area than seaweed to recover nutrients, but since they do not occupy the same trophic niche, comparisons are debatable. Aiming to achieve $100 \%$ bioremediation seems unrealistic in open-water IMTA systems regardless of the tropic niche considered and it is not necessarily a relevant goal for the farm; nonetheless, estimating the biomass and culture area of extractive organisms required for this purpose is a way to better design and scale future IMTA systems.

Compared to previous modeling studies combining finfish and sea cucumber species in an IMTA system, we included the limit to stocking density of sea cucumber when assessing the IMTA's biomitigation potential. Maximum stocking density was limited to $2000 \mathrm{~g} \mathrm{~m}^{-2}$, according to many experiments that showed a large effect of stocking density on sea cucumber growth (Battaglene et al., 1999; Hannah et al., 2013; T Lavitra et al., 2010; Li and Li, 2010; Pitt and Duy, 2004) and better growth performances at low densities (Slater and Carton, 2007; Yokoyama, 2013; Yu et al., 2014). Setting the maximum stocking density as a function of an organism's characteristics and its rearing constraints offers realistic insight into the bioremediation potential of sea cucumber in co-culture. Studies have demonstrated that beyond a critical density, sea cucumber growth decreased or stopped because of increased competition for resources, such as food and space. Critical density ranged from $200-400 \mathrm{~g} \mathrm{~m}^{-2}$ for $\mathrm{H}$. scabra culture in sea cages or pens under natural conditions, i.e. without any added food source (Juinio-Meñez et al., 2014; Namukose et al., 2016; Purcell and Simutoga, 2008). In contrast, H. scabra juveniles fed on particulate waste from a commercial land-based abalone aquaculture system grew well at a density of $1000 \mathrm{~g} \mathrm{~m}^{-2}$ with starch-amended effluent (Robinson et al., 2019), confirming that food availability and quality are critical factors regulating sea cucumber growth (Ren et al., 2010; Y. Ren et al., 2012). The higher stocking densities that did not inhibit sea cucumber growth were reported for Parastichopous californicus cultivated in suspended cages under sable fish (Anoplopoma fimbria), with optimal densities of 1400-2300 $\mathrm{g} \mathrm{m}^{-2}$ (Hannah et al., 2013). Some authors argued that, in IMTA, optimal densities for sea cucumber growth may not correspond to those that maximize bioremediation (Hannah et al., 2013; Namukose et al., 
2016; Zamora et al., 2018), and that the latter could be higher if particulate bioremediation is the primary aim of the co-culture. This may be true to some extent; nonetheless, given the current state of knowledge, it is difficult to believe that sea cucumber culture can exceed greatly the density limit of a few $\mathrm{kg}$ per $\mathrm{m}^{2}$. Finding the densities that optimize sea cucumber production or remediation potential is an important area of research for the future. Such practical limits to culture must be acknowledged to consider the degree to which sea cucumber and other species can extract solid waste from commercial finfish aquaculture.

The waste mitigation potential of sea cucumbers may not be sufficient to significantly reduce environmental effects of solid waste deposition on the seabed, and additional analyses are necessary to fully assess local ecological effects of IMTA systems. Compared to the deposition rates usually observed under finfish farms, the net solid uptake of sea cucumber $\left(0.645 \mathrm{~kg} \mathrm{~m}^{-2} \mathrm{yr}^{-1}\right)$ is too low to change the ecological status of the sediment in the seabed. On red drum farms (including the monoculture assessed here; see Chary et al. (in preparation)), like on other finfish farms (N.

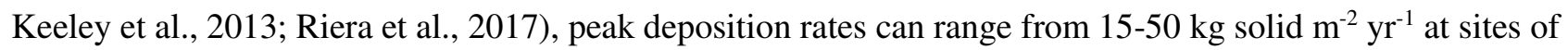
concentration. At these sites, adding sea cucumber under fish nets may not reduce waste fluxes significantly, and the impact, as a detectable change in sediment status, may occur from $0.5 \mathrm{~kg}$ solid $\mathrm{m}^{-2} \mathrm{yr}^{-1}$ (Chamberlain and Stucchi, 2007; Cromey et al., 2012, 2002; Findlay and Watling, 1997; Hargrave, 1994). However, we measured solid uptake of sea cucumbers below finfish cages and not in the seabed. Therefore, several important factors not included in this study will influence dispersion of finfish and sea cucumber solid waste in the water column and the degree of benthic impact. For instance, the spatial arrangement and design of suspended sea cucumber culture may influence local hydrodynamics (Zamora et al., 2018) by decreasing current velocities and reducing waste dispersion. Also, the chemical composition of sea cucumber feces will differ from those of finfish feces by having lower organic content (MacTavish et al., 2012; Neofitou et al., 2019; Paltzat et al., 2008), as will their physical characteristics (density, settling velocities), which are yet to be determined. Although necessary to assess local impacts comprehensively, modeling the benthic effect of the IMTA system, however, lay outside the scope of this study and is a perspective for further research. Also, we did not consider effects of dissolved nutrient waste, which will be higher for farms with sea cucumbers (Purcell, 2004) by ca. 0.1 and $1.4 \%$ for dissolved N and P, respectively, according to our results. Upscaling the analysis from local to larger spatial scales is necessary to properly represent their potential eutrophication impact. This is also true to account for other emissions (e.g. GHGs) occurring at the farm and other life-cycle stages and that can have impacts at the global scale. Finally, ending the assessment here would ignore that the IMTA system also produced additional biomass, which is another aim of IMTA systems. Therefore, to compare environmental 
performances of monoculture and IMTA systems fully, the analysis must be supplemented with more holistic impact assessment and related to the main functions of both systems, as performed in the LCA.

\subsection{LCIA: comparison of monoculture and IMTA}

In general, environmental impacts per t of fresh aquatic product were similar to the ranges and main trends of those found in literature. Contribution analysis revealed that feed production was the main driver of environmental impact in all impact categories of both systems, except for EU, for which farm operation (specifically finfish emissions) was the main source of impact, as commonly reported in aquaculture LCA reviews (Aubin, 2013; Bohnes et al., 2018; Parker, 2012). For all impact categories except EU, impacts of the monoculture and IMTA systems lay within the interquartile ranges of the results reviewed from 179 aquaculture systems (Bohnes et al., 2018). Our estimate of 123-124 $\mathrm{kg} \mathrm{PO}_{4}{ }^{3-}$ eq. (Fig. 3) largely exceeds the interquartile range of $32-74 \mathrm{~kg} \mathrm{PO}_{4}{ }^{3-}$ eq., suggesting that the red drum monoculture and IMTA systems assessed in this study have a higher EU impact than many other seafood systems. Differences in EU were smaller (14-36\% higher), however, when compared to other sea-cage systems in Tunisia and Greece (Abdou et al., 2017; Aubin et al., 2009), suggesting that most differences were likely due to the wide variety of systems analyzed and different methodological choices when performing the LCA (Bohnes and Laurent, 2019; Henriksson et al., 2012). Integrating seaweed culture into the IMTA system could address the dissolved nutrient niche (Troell et al., 2003) and reduce the EU impact (Jaeger et al., 2019). Given the domination of feed production in most impact categories, however, most improvement in the environmental performance of both systems studied is expected to come from decreasing the FCR of the finfish culture. Multiple factors influence the FCR, including feed composition and digestibility, rearing technology and practices (e.g. computerized feed-management systems) and the species cultured (Pelletier et al., 2009). These factors offer possibilities for improvements that should be considered to decrease the FCR.

The small differences observed between the monoculture and IMTA were due mainly to the unbalanced scales of the main species (i.e. finfish) and the added species (i.e. sea cucumber). In the IMTA system, the additional $3 \mathrm{t}$ of sea cucumbers (and $109 \mathrm{~kg}$ of edible protein) represented a minor increase in annual farm production; therefore, finfish production still drove the impacts. Mendoza Beltran et al. (2018) reported and discussed this issue when comparing impacts of a finfish monoculture (240 t) to those of the same farm in an IMTA system with oysters (244 t of aquatic products). They estimated similar differences between the two systems (0.4-1.8\% depending on the impact category) and reported that interpretation of their significance depended on the statistical test used, due to the high uncertainty, mainly in the LCI data. We also observed high uncertainties in our LCIA results. The estimated uncertainties were ca. 
10 times as high as the differences observed between impacts of the systems, meaning that they cannot be

differentiated; thus, both systems had similar impacts. In a recent study, a threshold of 10-30\% of difference, based on uncertainties quantified for multiple impact categories (Jolliet et al., 2010) was used to differentiate scenarios in LCA (Guérin-Schneider et al., 2018). According to the statistical analysis, some differences were still significant in our study, but they were probably artifacts caused by the large number of runs performed in the Monte Carlo analysis. Nevertheless, the ranking of IMTA compared to monoculture for each impact category can considered as a general trend and was confirmed for simulations with higher sea cucumber stocking densities (results not shown). In any case, these results confirmed the importance of performing uncertainty analysis in comparative LCAs to avoid overly simplistic conclusions.

Compared to the monoculture, the IMTA system tended to decrease EU and NPPU impacts but increase CC and

therefore, the decrease in EU was expected. On-farm production of organisms from a lower trophic level that ingested finfish waste for growth increased system productivity without an additional feed cost. This eco-intensification reduced the overall amount of feed used per unit of biomass produced, which explained the decrease in NPPU. IMTA is therefore an interesting way to use feed nutrients better and to mitigate some of the associated environmental impacts. However, ecological intensification of aquaculture (Aubin et al., 2019), through IMTA, shifted environmental burdens to energy-related global impact categories such as CC and CED. Energy use usually increases with system intensity in aquaculture (Aubin et al., 2006; Ayer and Tyedmers, 2009; Dekamin et al., 2015; SamuelFitwi et al., 2012) and is associated with increase in GHG emissions when energy originates from fossil sources (Pelletier et al., 2009). Finding such similarities with "classic" intensification is not surprising since finfish and sea cucumbers have similar life cycles, involving a hatchery stage followed by a grow-out stage in sea cages. Therefore, the increase in CC and CED in the IMTA system can be explained by the addition of new energy-demanding components (e.g. juvenile sea cucumber production) and energy inputs (e.g. on-farm fuel and electricity) related to sea cucumber culture. These components were not visible in the contribution analysis because of the large difference in production scales. Further intensification of this IMTA system by increasing sea cucumber production would therefore probably increase energy dependence of the system and the associated GHG emissions, unless it comes with a "greening" of the global energy system at all stages for both species, including hatchery, juvenile transport and farm activities. Close integration of farm activities and infrastructure becomes less likely in IMTA farms with more balanced production between primary and secondary species; therefore, environmental impacts will likely increase if 
sea cucumber production increases. Impacts will not necessarily transfer from local to global scales for other IMTA systems, particularly for those with species with less similar life cycles (e.g. finfish and seaweed). The same kind of local and global environmental assessment should be encouraged for these systems to select the most sustainable options for future aquaculture development.

\subsection{Other perspectives to improve environmental performances}

Local and global environmental benefits of the IMTA system were generally low because of the low productivity of sea cucumbers; increasing them will require finding practical methods to intensify sea cucumber production. One option is to investigate the choice and design of rearing structures that can increase the culture surface area and thus the bioremediation potential of the system. An initial approach could be to consider three-dimensional (3D) rearing structures to increase the biomass that can be grown per unit area (Robinson et al., 2011). For example, with a threelevel structures, the CS could be 'virtually' divided by three, i.e. 45:1 and WEE could increase to 2.20\%. However, food availability for sea cucumbers in a 3D structure will be affected by characteristics of the rearing system. The mesh sizes required to contain the sea cucumbers would greatly reduce the amount of farm particles entering the cages (Fortune, 2013; Zamora et al., 2018), with probably a gradual decrease in food availability from the top to the bottom of the rearing structure. Furthermore, accumulation of solids on top of the structure can also be problematic since it may deoxygenate water, which can kill sea cucumbers. Another option is benthic sea ranching of sea cucumbers, which consists of releasing juvenile animals on the seabed, often with minimal or no containment. Local environmental benefits may be increased by sea ranching, since the entire benthic area of the farm becomes available for culture, which means that more biomass can be produced. Chary et al. (in prep) estimated for the monoculture farm assessed here, that the largest benthic area receiving solid deposition rates higher or equal to $2.7 \mathrm{~kg} \mathrm{~m}^{-2} \mathrm{yr}^{-1}$ (corresponding to the SP of sea cucumbers) can extend up to $15000 \mathrm{~m}^{2}$. For this culture area, and assuming all other hypothesis being equal (except seeding, which becomes 54500 individuals), $30 \mathrm{t}$ of sea cucumbers could be produced annually, increasing WEE to $8.01 \%$. Moreover, in sea ranching culture sea cucumber feeding and burrowing on the seabed have a bioturbation effect, which can facilitate microbial organic degradation and enhance regeneration and mineralization of surface sediments (MacTavish et al., 2012; Purcell et al., 2016; Slater and Carton, 2009; Yuan et al., 2016). Sea ranching has been suggested to be more practical in IMTA than suspended culture at a large commercial scale because the latter may disrupt normal farming operations (Zamora et al., 2018). Sea ranching has potential major drawbacks, however: little monitoring of cultured animals and difficulties in harvesting, little distinction between cultured and wild animals, risks of benthic predator attacks (Hannah et al., 2013; Robinson and Pascal, 2011; Zamora et al., 2018), the physical characteristics of each site (e.g. depth and bathymetry profile, sediment type) that influence 
the ability of benthic species to settle, and the need to adapt the location of the animals on the seabed to the farm's organic footprint (Zhang and Kitazawa, 2016). Finding practical farming methods for sea cucumbers to be added to a pre-existing monoculture system thus remains a challenge. Farming structures will have to contain and secure the cultured stocks effectively while optimizing bioremediation, not compromising the normal farm-routine cycle and making the IMTA system at least as profitable as monoculture.

\section{Conclusion}

We assessed environmental performances of finfish monoculture and sea cucumber-finfish IMTA scenarios by i) focusing on the particulate waste bioremediation potential of sea cucumbers and ii) estimating environmental impacts of both systems with LCA per $\mathrm{kg}$ of edible protein and $\mathrm{t}$ of product. At its maximum ingestion capacity and in tropical water conditions, the sea cucumber H. scabra thus has good potential for aquaculture waste bioremediation if cultivated at high densities. However, given the current limits to stocking density observed for this species, its coculture in sea cages beneath finfish nets may decrease farm net particulate waste load and benthic impact only slightly. Intensification of sea cucumber culture seems possible to increase local environmental benefits, but further research is necessary to design rearing units that can optimize production and/or bioremediation and be practically integrated into existing finfish monoculture units. LCA impacts of the monoculture and IMTA systems differed little because of the large difference in production scales between finfish and sea cucumbers. IMTA showed better performance trends for EU and NPPU but larger impacts for CED and CC, generating an impact transfer between categories. These trends should be confirmed for large commercial IMTA farms with more balanced production scales between co-cultured species when the technology for sea cucumber culture becomes more advanced. Several other important environmental sustainability issues were not addressed in this study, such as potential disease transfer between cultured species or impacts of escaped animals on the local environment; they would need additional research to draw conclusions about broader environmental effects of the studied systems.

The use of generic metrics for comparing IMTA waste reduction efficiency and their use along with LCA resulted in a more holistic environmental assessment of the studied systems, addressing impact categories at both local and global scales. Such integrated model-based environmental analysis can be a powerful tool to predict the magnitude of environmental benefits that can be expected from new and complex production systems such as IMTA and to select the best co-culture options from an environmental viewpoint by maximizing resource use and minimizing environmental impacts. Its application to the case study of red drum and sea cucumber co-culture on Mayotte is one of many possibilities combining two or more organisms of different trophic levels and addressing other nutrient niches. Finally, given the differing statuses (trophic level, ecological role and culinary interest) and economic values of the 
631 species produced, and the multiple objectives of IMTA systems (biomitigation, production and revenue

632 diversification), we recommend including socio-economic criteria to fully assess the sustainability of future seafood 633 production systems.

634

\section{Acknowledgement}

636 This Ph.D. study was undertaken within the CAPAMAYOTTE project, Phase 2 (2015-2018), funded by the

637 Natural Marine Park of Mayotte and the Mayotte County Council. The authors gratefully acknowledge Dr. S. Purcell 638 for his technical advice on H. scabra culture. We also thank Dr. M.S. Corson for careful revision of the English. 


\section{DEB model parameters and assumptions for sea cucumber}

Parametrization of the Dynamic Energy Budget (DEB) model integrates data on life-history traits (e.g. age, weight and length at first feeding or puberty) and longitudinal data on weight, length and reproductive data over time (Kooijman, 2010). The full list of DEB parameters for Holothuria scabra can be retrieved freely from the "Add my Pet" database (Marques et al., 2018), but this appendix (Table A.1) shows only core parameters used to predict solid and dissolved waste emissions (Cf. section - "Conversion of DEB energy outputs to N and P fluxes").

Table A.1. Dynamic Energy Budget (DEB) parameters used in the present study for the tropical sea cucumber $H$. scabra for the reference temperature of $\mathrm{T}=20^{\circ} \mathrm{C}$. X corresponds to sea cucumber food resources (fish feces).

\begin{tabular}{lcccc}
\hline Parameter description & Symbol & Value & Unit & Source \\
\hline Core parameters & $\kappa$ & 0.98 & - & (AmP, 2019) \\
Allocation fraction to soma & $\kappa_{X}$ & 0.44 & - & This study \\
Assimilation efficiency & $\kappa_{G}$ & 0.80 & & (AmP, 2019) \\
Growth efficiency & $\kappa_{G o}$ & 0.95 & - & (AmP, 2019) \\
Reproduction efficiency & & & & \\
Temperature effect & $T_{A}$ & 8000 & $\mathrm{~K}$ & (AmP, 2019) \\
Arrhenius temperature & $T_{I}$ & 293 & $\mathrm{~K}$ & (AmP, 2019) \\
Reference temperature &
\end{tabular}

Supplementary parameters used to estimate dissolved emissions from DEB outputs

\section{Feed}

Energy density of feed (fish feces)

$\mathrm{N}$ to $\mathrm{P}$ stoichiometry of feed

$\begin{array}{cccc}E D_{\text {feed }} & 10464 & \mathrm{~J} \mathrm{~g} \mathrm{DW}^{-1} & \begin{array}{c}\text { This study } \\ \text { This study }\end{array} \\ N P_{X} & 2.42 & \text { mol:mol } & \\ & & & \text { mol:mol } \\ N P_{S C} & 30.05 & \text { (Clarke, 2008) } \\ N_{S C} & 6.95 & \% \mathrm{DW} & \text { (Ozer et al., 2004) } \\ P_{S C} & 0.64 & \% \mathrm{DW} & \text { This study } \\ \mu_{E N} & 3667 & \mathrm{~J} \mathrm{mmol} \mathrm{N}^{-1} & \text { This study }\end{array}$

\section{Sea cucumber}

$\mathrm{N}$ to $\mathrm{P}$ stoichiometry of sea cucumber

$\mathrm{N}$ content in sea cucumber

$\mathrm{P}$ content in sea cucumber

Energy yield of reserve

\section{Feces}

Conversion factor of unassimilated food

$\mu_{\text {NAfeed }}$

6166

$\mathrm{J}$ mmol N $\mathrm{N}^{-1}$

This study

Energy density of sea cucumber feces

$\mathrm{N}$ content in sea cucumber feces

ED feces

7717

$\mathrm{J} \mathrm{g} \mathrm{DW}^{-1}$

This study

$N_{\text {feces }}$

$0.57 \% \mathrm{DW}$

This study

$\mathrm{P}$ content in sea cucumber feces

$P_{\text {feces }}$

$1.89 \% \mathrm{DW}$

This study

651

This parameter set does not include lower and upper temperature limits, because of the lack of temperaturedependent data for this species. The default temperature correction factor was therefore used in this study (Marques et al. 2009) and complied with previous growth data up to $31^{\circ} \mathrm{C}$ (Thierry Lavitra et al., 2010) and $33^{\circ} \mathrm{C}$ (Kühnhold et al., 
655 2017). In the present study, the annual sea surface temperature time series in Miangani Bay, Longoni village, for

656 2016-2017 were used as reference for Mayotte lagoon. Water temperature ranged from $25.2^{\circ} \mathrm{C}$ on 18 October 2016 to $657 \quad 29.6^{\circ} \mathrm{C}$ on 6 April 2017.

658 The DEB model used in this study does not include the weight of gonads in total animal weight, because of 659 uncertainties in the reproductive cycle of H. scabra. It is known that sexual maturity appears at ca. $180 \mathrm{~g}$ (Juinio660 Meñez et al., 2013), and depending on the population, an annual, bi-annual or continuous reproductive cycle can be 661 observed (Conand, 1990; Morgan, 2000; Purwati, 2006; Rasolofonirina et al., 2005). In addition, Purwati (2006) and 662 Rasolofonirina et al. (2005) reported gonad indices for H. scabra in the Indian Ocean from 0-11\% of total body 663 weight, while Penina Tua Rahantoknam (2017) reported values up to $16 \%$. 
The DEB model, as well as energy or mass balance approaches, can be used to estimate fluxes of feces and their composition (Bureau et al., 2003; Cho and Bureau, 1998; Papatryphon et al., 2005). In DEB theory, assimilation efficiency $\left(\kappa_{\mathrm{X}}\right)$, which is the ratio of assimilated energy to ingested energy, is used to estimate the percentage of energy from food that is stored in the reserve of the animal. Unassimilated components are assumed to be excreted as feces by the animal. This coefficient is analogous to absorption efficiency in bioenergetics approaches or to apparent digestibility coefficients (ADC) in nutrient mass-balance approaches. In this study, $\kappa_{x}$ was estimated with a massbalance approach using ADC literature values obtained for $H$. scabra or other sea cucumber species (Table A.2). The amount of digested material was estimated by multiplying ADCs for primary nutritional fractions (i.e., protein, lipids, carbohydrates, fiber and ash) by their proximate amounts in sea cucumber feed (finfish feces), by assuming that total dry weight (DW) is the sum of nutritional fractions. Each nutritional fraction has a known gross energy density: respectively 23.6, 39.5, 17.2 and $7.8 \mathrm{~kJ} \mathrm{~g}^{-1}$ for protein, lipids, carbohydrates (Reid et al., 2018) and fiber (Kraisid Tontisirin. et al., 2003). Gross energy density in feed ( $\mathrm{ED}_{\text {feed }}$ ) was estimated by summing the energy in its nutritional fraction: $\mathrm{ED}_{\text {feed }}=10464 \mathrm{~J} \mathrm{~g} \mathrm{DW}^{-1}$ (Table A.2). Similarly, gross energy density of sea cucumber feces $\left(\mathrm{ED}_{\text {feces }}\right)$ was subtracted from the sum of energy in indigestible dietary material $\left(5897 \mathrm{~kJ}\right.$ for $0.76 \mathrm{~g}$ of feces), yielding $\mathrm{ED}_{\text {feces }}=$

$7717 \mathrm{~J} \mathrm{~g} \mathrm{DW}^{-1}$ (Table A.2). The energy assimilation efficiency was obtained from the ratio $\kappa_{X}=\frac{\text { Digested energy }}{E D_{\text {feed }}}=$ 43.65\%, with digested energy $=4567 \mathrm{~J}$ (Table A.2).

Table A.2. Nutritional mass balance approach for the sea cucumber $H$. scabra feeding on finfish feces in an integrated multi-trophic aquaculture system. Total dry weight (DW) was assumed to be the sum of protein, lipid, carbohydrates, fiber and ash fractions. The $\mathrm{N}$ fraction in finfish feces was subtracted from protein content using an N:protein ratio of $16 \%$.

\begin{tabular}{cccccccc}
\hline & $\begin{array}{c}\text { Content in feed } \\
\left.\text { (finfish feces }{ }^{1}\right)\end{array}$ & $\begin{array}{c}\text { Sea cucumber } \\
\text { digestibility } \\
\text { coefficients }\end{array}$ & $\begin{array}{c}\text { Digested material and } \\
\text { energy per g of feed } \\
\text { ingested }\end{array}$ & $\begin{array}{c}\text { Undigested material and } \\
\text { energy per g of feed } \\
\text { ingested }\end{array}$ \\
\cline { 2 - 9 } fraction & \% DW & $\mathrm{J}$ & $\%$ & $\mathrm{~g} \mathrm{~g}^{-1}$ & $\mathrm{~J} \mathrm{~g}^{-1}$ & $\mathrm{~g} \mathrm{~g}^{-1}(\%)$ & $\mathrm{J} \mathrm{g}^{-1}$ \\
\hline Protein & 14.85 & 3505 & $86.8^{2}$ & 0.12 & 2862 & $0.03(3.57)$ & 643 \\
\hline from $N$ & 2.38 & - & - & 0.02 & - & $0.00(0.57)$ & - \\
\hline Lipids & 3.75 & 1481 & $23.0^{3}$ & 0.01 & 341 & $0.03(3.78)$ & 1141 \\
\hline Carbohydrates & 13.27 & 2282 & $43.2^{2}$ & 0.06 & 985 & $0.08(9.87)$ & 1298 \\
\hline Fiber & 27.16 & 3196 & $11.9^{4}$ & 0.05 & 380 & $0.36(47.24)$ & 2815 \\
\hline Ash & 40.97 & 0 & 0.0 & 0.00 & 0 & $0.27(35.54)$ & 0.00 \\
\hline Phosphorus & 1.86 & - & $55.7^{5}$ & 0.01 & - & $0.01(1.08)$ & - \\
\hline Total & 100 & $\mathbf{1 0 ~ 4 6 4}$ & - & 0.24 & $\mathbf{4 5 6 7}$ & $0.76(100)$ & $\mathbf{5 8 9 7}$ \\
\hline
\end{tabular}


${ }^{1}$ Proximate composition of red drum feces calculated for animals fed with commercial Nutrima® diets (Chary et al. 2019)

${ }^{2}$ Mean coefficient obtained for an animal-ingredient-based diet for H. scabra (Orozco et al., 2014)

${ }^{3}$ Coefficient obtained for a sediment-based diet in the holothurian Molpadia musculus (Amaro et al., 2010)

${ }^{4}$ Coefficient obtained for red drum fed commercial diets (Chary et al. 2019). The low fiber digestion observed in this omnivorous finfish species was probably due to intestinal microbiota activity. In the absence of any relevant data on dietary fiber digestibility in holothurian species, we assumed the same partial digestibility for H. scabra.

${ }^{5}$ Calculated in this study 
Several equations are used in the DEB model to estimate $\mathrm{N}$ and $\mathrm{P}$ emissions in feces and dissolved inorganic emissions of sea cucumber (Table A.3). As suggested in "Add my Pet", the life cycle of $H$. scabra was modeled using a DEB model with metabolic acceleration between birth and metamorphosis (Kooijman, 2014). Description of a standard DEB model, the full list of equations and DEB nomenclature can be found elsewhere (Kooijman, 2010); therefore, we present only the methods used to estimate $\mathrm{N}$ and $\mathrm{P}$ fluxes into food, feces and dissolved emissions from DEB outputs.

Dissolved $\mathrm{N}$ and P emissions from sea cucumber were estimated in the DEB model based on the equations of Pete et al. (2018) (see also Pete et al. in prep) (Table A.3). The conversion factor $\mu_{\mathrm{UFF}}$ is used to convert the energy from undigested (unassimilated) finfish feces into N. We calculated $\mu_{\text {feces }}$ from the equation $\mu_{\text {feces }}=\frac{E D_{\text {feed }} \cdot M_{N}}{N_{\text {feed }}}=6166 \mathrm{~J}$ mmol N $\mathrm{N}^{-1}$, with $\mathrm{M}_{\mathrm{N}}=0.014 \mathrm{~g} \mathrm{mmol}^{-1}$. The N:P stoichiometry in the animal and the feed was respectively taken from Clarke (2008) for the holothurian Heterocucumis steineni and from Chary et al. (2019) for red drum feces. The energy assimilated from feed is incorporated into reserves and used for maintenance, growth and maturity in juveniles or reproduction in adults. The energy used for maintenance, growth, and gonad formation can be converted into $\mathrm{NH}_{4}{ }^{+}$ and $\mathrm{PO}_{4}{ }^{3-}$ fluxes (in mmol day ${ }^{-1}$ ) using the conversion factor $\mu_{\mathrm{EN}}\left(\right.$ in $\mathrm{J}$ mmol ${ }^{-1}$ ). This conversion factor can be obtained by dividing the chemical potential in sea cucumber reserves of $550000 \mathrm{~J}^{\mathrm{mol} \mathrm{C}} \mathrm{C}^{-1}$ (Marques et al., 2018) by the $\mathrm{N}: \mathrm{C}$ ratio in the organic matter of the reserves, which is $0.15 \mathrm{~mol} \mathrm{~N} \mathrm{~mol} \mathrm{C}^{-1}$ (Marques et al., 2018).

Table A.3. Equations used in the Dynamic Energy Budget (DEB) model to estimate $\mathrm{N}$ and $\mathrm{P}$ in food, feces and from solid and dissolved waste emissions of sea cucumber, modified from Pete et al. (2018) (see also Pete et al. in prep). Equations describing energy fluxes and variable differential equations in DEB theory can be found elsewhere (Kooijman, 2010).

\begin{tabular}{|c|c|c|}
\hline Equation & Variable and parameters description & Unit \\
\hline \multirow{3}{*}{$I F F=\dot{p}_{X} \cdot E D_{\text {feed }}$} & IFF: Ingested finfish feces & $\mathrm{g} \mathrm{DW} \mathrm{d}^{-1}$ \\
\hline & $\dot{p}_{X}:$ Ingestion rate & $\mathrm{J} \mathrm{d}^{-1}$ \\
\hline & ED feces: Energy density in feed & $\mathrm{Jg} \mathrm{DW}^{-1}$ \\
\hline \multirow{3}{*}{$U F F=\left(1-\kappa_{X}\right) \cdot \dot{p}_{X} \cdot E D_{\text {feces }}$} & UFF: Undigested finfish feces & $\mathrm{g} \mathrm{DW} \mathrm{d}^{-1}$ \\
\hline & $\kappa_{X}:$ Assimilation efficiency & $\%$ \\
\hline & $\mathrm{ED}_{\text {feces}}$ : Energy density in feces & $\mathrm{Jg} \mathrm{DW}^{-1}$ \\
\hline \multirow{2}{*}{$F_{N}=F \cdot N_{\text {feces }}$} & $\mathrm{F}_{\mathrm{N}}: \mathrm{N}$ solid emission from feces & $\mathrm{g} \mathrm{N} \mathrm{d}^{-1}$ \\
\hline & $\mathrm{N}_{\text {feces: }}: \mathrm{N}$ content in feces & $\%$ \\
\hline \multirow{2}{*}{$F_{P}=F \cdot P_{\text {feces }}$} & $\mathrm{F}_{\mathrm{P}}: \mathrm{P}$ solid emission from feces & $\mathrm{g} \mathrm{P} \mathrm{d}^{-1}$ \\
\hline & $\mathrm{P}_{\text {feces: }} \mathrm{P}$ content in feces & $\%$ \\
\hline
\end{tabular}




\begin{tabular}{|c|c|c|}
\hline$N_{\text {regen }}=0$ because $N P_{X}<N P_{S C}$ & $N_{\text {regen }}:$ Regeneration of excess $\mathrm{N}$ & ${\mathrm{mmol} \mathrm{N}-\mathrm{NH}_{4}+\mathrm{d}^{-1}}^{-1}$ \\
\hline$P_{\text {regen }}=\frac{\dot{p}_{A}}{\mu_{U F F}} \cdot\left(\frac{1}{N P_{S C}}-\frac{1}{N P_{O}}\right)$ & $\begin{array}{l}P_{\text {regen }}: \text { Regeneration of excess } \mathrm{N} \\
\dot{p}_{A}: \text { Assimilation rate } \\
\mu_{U F F}: \text { Conversion factor of undigested finfish } \\
\text { feces }\end{array}$ & $\begin{array}{l}{\mathrm{mmol} \mathrm{P}-\mathrm{PO}_{4}{ }^{3-} \mathrm{d}^{-1}}_{\mathrm{J}} \\
\mathrm{J} \mathrm{mmol} \mathrm{N}\end{array}$ \\
\hline$C M C=\frac{\dot{p}_{M 1}+\dot{p}_{J}}{\mu_{E N}}$ & $\begin{array}{l}C M C: \text { Conversion of maintenance cost } \\
\dot{p}_{M 1}: \text { Structural maintenance rate } \\
\dot{p}_{J}: \text { Maturity maintenance rate } \\
\mu_{E N}: \text { Energy yield of reserve }\end{array}$ & 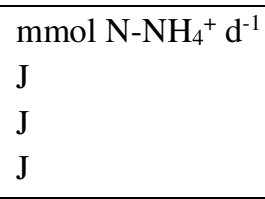 \\
\hline$C G C=\frac{\dot{p}_{G} \cdot\left(1-\kappa_{G}\right)}{\mu_{E N}}$ & $\begin{array}{l}C G C: \text { Conversion of growth cost } \\
\dot{p}_{G}: \text { Structural growth rate } \\
\kappa_{G}: \text { Growth efficiency }\end{array}$ & 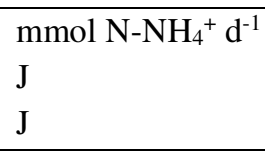 \\
\hline$C C G P=\frac{\dot{p}_{G o} \cdot\left(1-\kappa_{G o}\right)}{\mu_{E N}}$ & $\begin{array}{l}C C G P: \text { Conversion of gamete production cost } \\
\dot{p}_{G o}: \text { Gonad allocation rate } \\
\kappa_{G o}: \text { Reproduction efficiency }\end{array}$ & $\begin{array}{l}{\mathrm{mmol} \mathrm{N}-\mathrm{NH}_{4}+\mathrm{d}^{-1}}_{\mathrm{J}} \\
\mathrm{J}\end{array}$ \\
\hline$\frac{d N \cdot N H_{4}}{d t}=(C M C+C G C+C C G P) \cdot M_{N \cdot N H_{4}}$ & $\begin{array}{l}\frac{d N . N H_{4}}{d t}: \text { Total emissions of } \mathrm{N}-\mathrm{NH}_{4} \\
M_{N . N H_{4}}: \text { Molar mass of } \mathrm{N}\end{array}$ & $\begin{array}{l}\mathrm{kg} \mathrm{N}-\mathrm{NH}_{4}{ }^{+} \mathrm{d}^{-1} \\
\mathrm{~kg} \mathrm{mmol}^{-1}\end{array}$ \\
\hline$\frac{d P . P O_{4}}{d t}=\left(P_{\text {regen }}+\frac{C M C+C G C+C C G P}{N P_{S C}}\right) \cdot M_{P . P O_{4}}$ & $\begin{array}{l}\frac{d P . P O_{4}}{d t}: \text { Total emissions of } \mathrm{P}^{-\mathrm{PO}_{4}} \\
M_{P . P O_{4}}: \text { Molar mass of } \mathrm{P}\end{array}$ & $\begin{array}{l}\mathrm{kg} \mathrm{P}-\mathrm{PO}_{4}{ }^{3-} \mathrm{d}^{-1} \\
\mathrm{~kg} \mathrm{mmol}^{-1}\end{array}$ \\
\hline
\end{tabular}




\section{Approach to estimate $\mathbf{P}$ digestibility in sea cucumber}

No data were found for P digestibility in $\mathrm{H}$. scabra or other sea cucumbers; therefore, the fraction of $\mathrm{P}$ assimilated from feed $(\mathrm{As} P)$ was back-estimated using a mass-balance approach and was used to calculate $\mathrm{P}$ emissions in sea cucumber feces. In the mass-balance approach, the digested nutrient fraction equals the nutrients excreted in dissolved emissions and those retained in biomass gain (Cho and Kaushik, 1990). Dissolved P emissions $\left(\frac{d P . P O_{4}}{d t}\right)$ from a $10 \mathrm{~g}$ juvenile (age $=88$ days) to a final weight of $709 \mathrm{~g}$ (age $=453$ days) were estimated with the DEB model as $8.46 \mathrm{~g}$ in the temperature time series (Cf. section "DEB model parameters and assumptions for sea cucumber") and using an $\mathrm{f}$ value set to 1. $\mathrm{P}$ content $\left(\mathrm{P}_{\mathrm{SC}}\right)$ in sea cucumber, required to calculate the $\mathrm{P}$ retained in biomass, was calculated as $P_{S C}=\frac{N_{S C} \cdot D W_{S C}}{M_{N}} \cdot \frac{M_{P}}{N P_{S C}}=0.64 \% \mathrm{DW}^{-1}$, with $\mathrm{N}$ content in sea cucumber, $\mathrm{N}_{\mathrm{SC}}=6.95 \% \mathrm{DW}^{-1}$ (subtracted from protein content in Ozer et al. 2004); DW ratio in sea cucumber $\left(\mathrm{DW}_{\mathrm{SC}}\right)=14.51 \%$ (mean value in Ozer et al. 2004) and $\mathrm{P}$ molar mass $\left(\mathrm{M}_{\mathrm{P}}\right)=31 \mathrm{~g} \mathrm{~mol}^{-1}$. Using $\mathrm{P}_{\mathrm{SC}}$ and $\mathrm{DW}_{\mathrm{SC}}$, the $\mathrm{P}$ retained in biomass was estimated as $0.65 \mathrm{~g} \mathrm{DW}$ for a biomass gain of 709-10 $=699 \mathrm{~g}$. Following mass-balance principles, the $\mathrm{P}$ in feed assimilated by sea cucumbers is therefore the sum of P retained in biomass and P dissolved over the simulated period (i.e. $9.11 \mathrm{~g}$ in 365 days). DEB predicted cumulative food ingestion of $879 \mathrm{~g}$ finfish feces DW $\mathrm{yr}^{-1}$ per individual in the culture cycle. With a $\mathrm{P}$ content in feed $\left(\mathrm{P}_{\text {feed }}\right)$ of $1.86 \%$ (Table A.2), cumulative $\mathrm{P}$ inputs in feed over the period were thus $16.36 \mathrm{~g}$. Finally, we estimated the percentage of $\mathrm{P}$ assimilated from feed (i.e. the ratio of assimilated $\mathrm{P}$ to total $\mathrm{P}$ input in feed) as Asp $=$ 55.7\%. This value was used in the mass-balance calculation to calculate the $\mathrm{P}$ content in sea cucumber feces $\left(\mathrm{P}_{\text {feces }}\right)$. 
Abdou, K., Aubin, J., Romdhane, M.S., Le Loc'h, F., Lasram, F.B.R., 2017. Environmental assessment of seabass (Dicentrarchus labrax) and seabream (Sparus aurata) farming from a life cycle perspective: A case study of a Tunisian aquaculture farm. Aquaculture 471, 204-212. https://doi.org/10.1016/j.aquaculture.2017.01.019

Agudo, N., 2006. Sandfish Hatchery Techniques. Nouméa, New Caledonia. https://doi.org/10.1002/joc.4659

Alexander, K.A., Freeman, S., Potts, T., 2016. Navigating uncertain waters: European public perceptions of integrated multi trophic aquaculture (IMTA). Environ. Sci. Policy 61, 230-237. https://doi.org/10.1016/J.ENVSCI.2016.04.020

Amaro, T., Bianchelli, S., Billett, D.S.M., Cunha, M.R., Pusceddu, A., Danovaro, R., 2010. The trophic biology of the holothurian Molpadia musculus: implications for organic matter cycling and ecosystem functioning in a deep submarine canyon. Biogeosciences 7, 2419-2432. https://doi.org/10.5194/bg-7-2419-2010

AmP, 2019. Add-my-Pet Collection, Online Database of DEB parameters, Implied Properties and Referenced Underlying Data. [WWW Document]. URL https://www.bio.vu.nl/thb/deb/deblab/add_my_pet/ (accessed 1.16.19).

Aubin, J., 2013. Life Cycle Assessment as applied to environmental choices regarding farmed or wild-caught fish. CAB Rev. Perspect. Agric. Vet. Sci. Nutr. Nat. Resour. 8. https://doi.org/10.1079/PAVSNNR20138011

Aubin, J., Callier, M., Rey-Valette, H., Mathé, S., Wilfart, A., Legendre, M., Slembrouck, J., Caruso, D., Chia, E., Masson, G., Blancheton, J.P., Ediwarman, Haryadi, J., Prihadi, T.H., de Matos Casaca, J., Tamassia, S.T.J., Tocqueville, A., Fontaine, P., 2019. Implementing ecological intensification in fish farming: definition and principles from contrasting experiences. Rev. Aquac. 11, 149-167. https://doi.org/10.1111/raq.12231

Aubin, J., Papatryphon, E., van der Werf, H.M.G., Chatzifotis, S., 2009. Assessment of the environmental impact of carnivorous finfish production systems using life cycle assessment. J. Clean. Prod. 17, 354-361. https://doi.org/10.1016/j.jclepro.2008.08.008

Aubin, J., Papatryphon, E., Van der Werf, H.M.G., Petit, J., Morvan, Y.M., 2006. Characterisation of the environmental impact of a turbot (Scophthalmus maximus) re-circulating production system using Life Cycle Assessment. Aquaculture 261, 12591268. https://doi.org/10.1016/j.aquaculture.2006.09.008

Avadí, A., Fréon, P., 2013. Life cycle assessment of fisheries: A review for fisheries scientists and managers. Fish. Res. 143, 2138. https://doi.org/10.1016/J.FISHRES.2013.01.006

Ayer, N.W., Tyedmers, P.H., 2009. Assessing alternative aquaculture technologies: life cycle assessment of salmonid culture systems in Canada. J. Clean. Prod. 17, 362-373. https://doi.org/10.1016/J.JCLEPRO.2008.08.002

Barrington, K., Chopin, T., Robinson, S., 2009. Integrated multi-trophic aquaculture (IMTA) in marine temperate waters, in: Soto, D. (Ed.), Integrated Mariculture: A Global Review. FAO Fisheries and Aquaculture Technical Paper. Rome, FAO, pp. 7-46. https://doi.org/10.1016/S0044-8486(03)00469-1

Barrington, K., Ridler, N., Chopin, T., Robinson, S., Robinson, B., 2010. Social aspects of the sustainability of integrated multitrophic aquaculture. Aquac. Int. 18, 201-211. https://doi.org/10.1007/s10499-008-9236-0

Battaglene, S.C., Bell, J.D., 2004. The restocking of sea cucumbers in the Pacific Islands, in: Bartley, D.M., Leber, K.M. (Eds.), Marine Ranching. Food and Agriculture Organization of the United Nations, Rome, pp. 109-132.

Battaglene, S.C., Seymour, J.E., Ramofafia, C., 1999. Survival and growth of cultured juvenile sea cucumbers, Holothuria scabra. Aquaculture 178, 293-322. https://doi.org/10.1016/S0044-8486(99)00130-1

Bohnes, F.A., Hauschild, M.Z., Schlundt, J., Laurent, A., 2018. Life cycle assessments of aquaculture systems: a critical review of reported findings with recommendations for policy and system development. Rev. Aquac. 1-19. https://doi.org/10.1111/raq.12280

Bohnes, F.A., Laurent, A., 2019. LCA of aquaculture systems: methodological issues and potential improvements. Int. J. Life Cycle Assess. 24, 324-337. https://doi.org/10.1007/s11367-018-1517-X

Borja, Á., Rodríguez, J.G., Black, K., Bodoy, A., Emblow, C., Fernandes, T.F., Forte, J., Karakassis, I., Muxika, I., Nickell, T.D., Papageorgiou, N., Pranovi, F., Sevastou, K., Tomassetti, P., Angel, D., 2009. Assessing the suitability of a range of benthic indices in the evaluation of environmental impact of fin and shellfish aquaculture located in sites across Europe. Aquaculture 293, 231-240. https://doi.org/10.1016/j.aquaculture.2009.04.037

Bravo, F., Grant, J., 2018. Modelling sediment assimilative capacity and organic carbon degradation efficiency at marine fish farms. Aquac. Environ. Interact. 10, 309-328. https://doi.org/10.3354/aei00267

Bureau, D.P., Gunther, S.J., Cho, C.Y., 2003. Chemical Composition and Preliminary Theoretical Estimates of Waste Outputs of Rainbow Trout Reared in Commercial Cage Culture Operations in Ontario. N. Am. J. Aquac. 65, 33-38. https://doi.org/10.1577/1548-8454(2003)065<0033:CCAPTE>2.0.CO;2 
Buschmann, A.H., Hernández-González, M.C., Aranda, C., Chopin, T., Neori, A., Halling, C., Troell, M., 2008. Mariculture Waste Management, in: Jørgensen, S.E., Fath, B.D. (Eds.), Encyclopedia of Ecology. Elsevier, Oxford, pp. 2211-2217. https://doi.org/10.1016/B978-008045405-4.00045-8

Cabinet Gressard consultants, Monfort, M., SAFIDY, 2013. Schéma régional de développement de l'aquaculture de Mayotte (SRDAM) - Tome 3: rapports des experts.

Cao, L., Diana, J.S., Keoleian, G.A., 2013. Role of life cycle assessment in sustainable aquaculture. Rev. Aquac. 5, 61-71. https://doi.org/10.1111/j.1753-5131.2012.01080.x

Carras, M.A., Knowler, D., Pearce, C.M., Hamer, A., Chopin, T., Weaire, T., 2019. A discounted cash-flow analysis of salmon monoculture and Integrated Multi-Trophic Aquaculture in eastern Canada. Aquac. Econ. Manag. 1-21. https://doi.org/10.1080/13657305.2019.1641572

Chamberlain, J., Stucchi, D., 2007. Simulating the effects of parameter uncertainty on waste model predictions of marine finfish aquaculture. Aquaculture 272, 296-311. https://doi.org/DOI 10.1016/j.aquaculture.2007.08.051

Chary, K., Fiandrino, A., Covès, D., Aubin, J., Falguière, J.C., Callier, M.D., 2019. Modeling sea cage outputs for data-scarce areas: application to red drum (Sciaenops ocellatus) aquaculture in Mayotte, Indian Ocean. Aquac. Int. https://doi.org/10.1007/s10499-019-00351-z

Cho, C.Y., Bureau, D.P., 1998. Development of bioenergetic models and the fish-PrFEQ software to estimate production, feeding ration and waste output in aquaculture. Aquat. Living Resour. 11, 199-210. https://doi.org/10.1016/S0990-7440(98)89002-5

Cho, C.Y., Kaushik, S.J., 1990. Nutritional energetics in fish: energy and protein utilization in rainbow trout (Salmo gairdneri), in: World Reviews in Nutrition and Dietetics. Karger Publishers, pp. 132-172. https://doi.org/10.1159/000417529

Chopin, T., Cooper, J.A., Reid, G., Cross, S., Moore, C., 2012. Open-water integrated multi-trophic aquaculture: environmental biomitigation and economic diversification of fed aquaculture by extractive aquaculture. Rev. Aquac. 4, 209-220. https://doi.org/10.1111/j.1753-5131.2012.01074.x

Clarke, A., 2008. Ecological stoichiometry in six species of Antarctic marine benthos. Mar. Ecol. Prog. Ser. 369, 25-37. https://doi.org/10.3354/meps07670

Conand, C., 1990. The fishery resources of Pacific island countries. Part 2: Holothurians, FAO Fish. Tech. Paper 272.

Cranford, P., Reid, G., Robinson, S., 2013. Open water integrated multi-trophic aquaculture: constraints on the effectiveness of mussels as an organic extractive component. Aquac. Environ. Interact. 4, 163-173. https://doi.org/10.3354/aei00081

Cromey, C.J., Nickell, T.D., Black, K.D., 2002. DEPOMOD—modelling the deposition and biological effects of waste solids from marine cage farms. Aquaculture 214, 211-239. https://doi.org/10.1016/S0044-8486(02)00368-X

Cromey, C.J., Thetmeyer, H., Lampadariou, N., Black, K.D., Kögeler, J., Karakassis, I., 2012. MERAMOD: Predicting the deposition and benthic impact of aquaculture in the eastern Mediterranean Sea. Aquac. Environ. Interact. 2, 157-176. https://doi.org/10.3354/aei00034

Cubillo, A.M., Ferreira, J.G., Robinson, S.M.C., Pearce, C.M., Corner, R.A., Johansen, J., 2016. Role of deposit feeders in integrated multi-trophic aquaculture - A model analysis. Aquaculture 453, 54-66. https://doi.org/10.1016/j.aquaculture.2015.11.031

Dekamin, M., Veisi, H., Safari, E., Liaghati, H., Khoshbakht, K., Dekamin, M.G., 2015. Life cycle assessment for rainbow trout (Oncorhynchus mykiss) production systems: a case study for Iran. J. Clean. Prod. 91, 43-55. https://doi.org/10.1016/J.JCLEPRO.2014.12.006

Edwards, P., 2015. Aquaculture environment interactions: Past, present and likely future trends. Aquaculture 447, 2-14. https://doi.org/10.1016/j.aquaculture.2015.02.001

Eeckhaut, I., Lavitra, T., Rasoforinina, R., Rabenevanana, M.W., Gildas, P., Jangoux, M., 2008. Madagascar Holothurie SA: The first trade company based on sea cucumber aquaculture in Madagascar. SPC Beche-de-mer Inf. Bull. 28, 22-23.

Falguière, J.-C., 2011. L'ombrine ocellée, Sciaenops ocellatus : biologie, pêche, aquaculture et marché, Quae. ed. Savoir faire.

Filgueira, R., Guyondet, T., Reid, G.K., Grant, J., Cranford, P.J., 2017. Vertical particle fluxes dominate integrated multi-trophic aquaculture (IMTA) sites: Implications for shellfish-finfish synergy. Aquac. Environ. Interact. 9, 127-143. https://doi.org/10.3354/aei00218

Findlay, R., Watling, L., 1997. Prediction of benthic impact for salmon net-pens based on the balance of benthic oxygen supply and demand. Mar. Ecol. Prog. Ser. 155, 147-157. https://doi.org/10.3354/meps155147

Fortune, A.C., 2013. Integrated Multi-Trophic Aquaculture with the California Sea Cucumber (Parastichopus californicus): Investigating Grow-out Cage Design for Juvenile Sea Cucumbers Co-cultured with Pacific Oysters (Crassostrea gigas). Simon Fraser University. 
Frischknecht, R., Jungbluth, N., Althaus, H.J., Doka, G., Dones, R., Hirschier, R., Hellweg, S., Humbert, S., Margni, M., Nemecek, T., Speilmann, M., 2004. Implementation of Life Cycle Impact Assessment Methods (Version 1.1). Eco-Invent Report No. 3. Dübendorf.

Giles, H., 2008. Using Bayesian networks to examine consistent trends in fish farm benthic impact studies. Aquaculture 274, $181-$ 195. https://doi.org/10.1016/J.AQUACULTURE.2007.11.020

Granada, L., Sousa, N., Lopes, S., Lemos, M.F.L., 2016. Is integrated multitrophic aquaculture the solution to the sectors' major challenges? - a review. Rev. Aquac. 8, 283-300. https://doi.org/10.1111/raq.12093

Guérin-Schneider, L., Tsanga-Tabi, M., Roux, P., Catel, L., Biard, Y., 2018. How to better include environmental assessment in public decision-making: Lessons from the use of an LCA-calculator for wastewater systems. J. Clean. Prod. 187, 10571068. https://doi.org/10.1016/J.JCLEPRO.2018.03.168

Guinée, J.B., Heijungs, R., Huppes, G., Kleijn, R., de Koning, A., van Oers, L., Wegener Sleeswijk, A., Suh, S., Udo de Haes, H.A., de Bruijn, H., van Duin, R., Huijbregts, M.A.J., Gorrée, M., 2002. Handbook on Life Cycle Assessment. An Operational Guide to the ISO Standards. Kluwer Academic Publishers, Dordrecht, The Netherland.

Hannah, L., Pearce, C.M., Cross, S.F., 2013. Growth and survival of California sea cucumbers (Parastichopus californicus) cultivated with sablefish (Anoplopoma fimbria) at an integrated multi-trophic aquaculture site. Aquaculture 406-407, 3442. https://doi.org/10.1016/J.AQUACULTURE.2013.04.022

Hargrave, B.T. (Ed.), 2005. Environmental Effects of Marine Finfish Aquaculture, Handbook of Environmental Chemistry. Springer-Verlag, Berlin/Heidelberg. https://doi.org/10.1007/b12227

Hargrave, B.T., 1994. A benthic enrichment index, in: Modeling Benthic Impacts of Organic Enrichment from Marine Aquaculture. Canadian Technical Report. Fish. Aquat. Sci. 1949. pp. 79-91.

Henriksson, P.J.G., Guinée, J.B., Heijungs, R., De Koning, A., Green, D.M., 2014. A protocol for horizontal averaging of unit process data - Including estimates for uncertainty. Int. J. Life Cycle Assess. 19, 429-436. https://doi.org/10.1007/s11367013-0647-4

Henriksson, P.J.G., Guinée, J.B., Kleijn, R., de Snoo, G.R., 2012. Life cycle assessment of aquaculture systems—a review of methodologies. Int. J. Life Cycle Assess. 17, 304-313. https://doi.org/10.1007/s11367-011-0369-4

Holmer, M., Black, K., Duarte, C.M., Marbà, N., Karakassis, I. (Eds.), 2008. Aquaculture in the Ecosystem. Springer, Dordrecht, The Netherlands. https://doi.org/10.1017/CBO9781107415324.004

Howarth, R.W., 1988. Nutrient Limitation of Net Primary Production in Marine Ecosystems. Annu. Rev. Ecol. Syst. 19, 89-110. https://doi.org/10.1146/annurev.es.19.110188.000513

ISO, 2006a. Environmental management — life cycle assessment — requirements and guidelines. ISO 14044.

ISO, 2006b. Environmental management — life cycle assessment — principles and framework. ISO 14044.

Jaeger, C., Foucard, P., Tocqueville, A., Nahon, S., Aubin, J., 2019. Mass balanced based LCA of a common carp-lettuce aquaponics system. Aquac. Eng. 84, 29-41. https://doi.org/10.1016/J.AQUAENG.2018.11.003

Jessen, C., Bednarz, V.N., Rix, L., Teichberg, M., Wild, C., 2015. Marine Eutrophication, in: Environmental Indicators. Springer Netherlands, Dordrecht, pp. 177-203. https://doi.org/10.1007/978-94-017-9499-2_11

Jolliet, O., Saadé, M., Crettaz, P., Shaked, S., Soucy, G., Houillon, G., 2010. Analyse du Cycle de Vie, Comprendre et réaliser un écobilan, 2ème édition, Presses Po. ed, Science \& Ingénierie de l'Environnement.

Juinio-Meñez, M.A., Evangelio, J.C., Miralao, S.J.A., 2014. Trial grow-out culture of sea cucumber Holothuria scabra in sea cages and pens. Aquac. Res. 45, 1332-1340. https://doi.org/10.1111/are.12078

Juinio-Meñez, M.A., Evangelio, J.C., Olavides, R.D., Paña, M.A.S., De Peralta, G.M., Edullantes, C.M.A., Rodriguez, B.D.R., Casilagan, I.L.N., 2013. Population Dynamics of Cultured Holothuria scabra in a Sea Ranch: Implications for Stock Restoration. Rev. Fish. Sci. 21, 424-432. https://doi.org/10.1080/10641262.2013.837282

Karakassis, I., 2000. Impact of cage farming of fish on the seabed in three Mediterranean coastal areas. ICES J. Mar. Sci. 57 , 1462-1471. https://doi.org/10.1006/jmsc.2000.0925

Keeley, N., Cromey, C., Goodwin, E., Gibbs, M., Macleod, C., 2013. Predictive depositional modelling (DEPOMOD) of the interactive effect of current flow and resuspension on ecological impacts beneath salmon farms. Aquac. Environ. Interact. 3, 275-291. https://doi.org/10.3354/aei00068

Keeley, N.B., Forrest, B.M., Macleod, C.K., 2013. Novel observations of benthic enrichment in contrasting flow regimes with implications for marine farm monitoring and management. Mar. Pollut. Bull. 66, 105-116. https://doi.org/10.1016/j.marpolbul.2012.10.024

Kim, Y.C., Sasaki, S., Yano, K., Ikebukuro, K., Hashimoto, K., Karube, I., 2000. Relationship between theoretical oxygen 
demand and photocatalytic chemical oxygen demand for specific classes of organic chemicals. Analyst 125, 1915-1918. https://doi.org/10.1039/b007005j

Kooijman, S.A.L.M., 2014. Metabolic acceleration in animal ontogeny: An evolutionary perspective. J. Sea Res. 94, $128-137$. https://doi.org/10.1016/J.SEARES.2014.06.005

Kooijman, S.A.L.M., 2010. Dynamic energy budget theory for metabolic organisation, third edition, Dynamic Energy Budget Theory for Metabolic Organisation, Third Edition. Cambridge University Press, Cambridge. https://doi.org/10.1017/CBO9780511805400

Kooijman, S.A.L.M., 2000. Dynamic Energy and Mass Budgets in Biological Systems. Cambridge University Press. https://doi.org/10.1017/CBO9780511565403

Kraisid Tontisirin., MacLean, W.C., Warwick, P., 2003. Food energy : methods of analysis and conversion factors. Food and Agriculture Organization of the United Nations, Rome.

Kühnhold, H., Kamyab, E., Novais, S., Indriana, L., Kunzmann, A., Slater, M., Lemos, M., 2017. Thermal stress effects on energy resource allocation and oxygen consumption rate in the juvenile sea cucumber, Holothuria scabra (Jaeger, 1833). Aquaculture 467, 109-117. https://doi.org/10.1016/J.AQUACULTURE.2016.03.018

Lavitra, T., Fohy, N., Gestin, P.-G., Rasolofonirina, R., Eeckhaut, I., 2010. Effect of water temperature on the survival and growth of endobenthic Holothuria scabra (Echinodermata: Holothuroidea) juveniles reared in outdoor ponds. SPC Beche-de-mer Inf. Bull. https://doi.org/10.1016/j.cct.2017.01.003

Lavitra, T., Rachelle, D., Rasolofonirina, R., Jangoux, M., Eeckhaut, I., 2008. Processing and marketing of holothurians in the Toliara region, southwestern Madagascar. Beche-de-Mer Bull. 28, 24-33.

Lavitra, T., Rasolofonirina, R., Eeckhaut, I., 2010. The Effect of Sediment Quality and Stocking Density on Survival and Growth of the Sea Cucumber Holothuria scabra Reared in Nursery Ponds and Sea Pens. West. Indian Ocean J. Mar. Sci. https://doi.org/10.4314/wiojms.v8i1.56678

Li, L., Li, Q., 2010. Effects of stocking density, temperature, and salinity on larval survival and growth of the red race of the sea cucumber Apostichopus japonicus (Selenka). Aquac. Int. 18, 447-460. https://doi.org/10.1007/s10499-009-9256-4

MacDonald, C.L.E., Stead, S.M., Slater, M.J., 2013. Consumption and remediation of European Seabass (Dicentrarchus labrax) waste by the sea cucumber Holothuria forskali. Aquac. Int. 21, 1279-1290. https://doi.org/10.1007/s10499-013-9629-6

MacTavish, T., Stenton-Dozey, J., Vopel, K., Savage, C., 2012. Deposit-Feeding Sea Cucumbers Enhance Mineralization and Nutrient Cycling in Organically-Enriched Coastal Sediments. PLoS One 7, e50031. https://doi.org/10.1371/journal.pone.0050031

Magill, S.H., Thetmeyer, H., Cromey, C.J., 2006. Settling velocity of faecal pellets of gilthead sea bream (Sparus aurata L.) and sea bass (Dicentrarchus labrax L.) and sensitivity analysis using measured data in a deposition model. Aquaculture 251, 295-305. https://doi.org/10.1016/j.aquaculture.2005.06.005

Marín, T., Wu, J., Wu, X., Ying, Z., Lu, Q., Hong, Y., Wang, X., Yang, W., 2019. Resource use in mariculture: A case study in Southeastern China. Sustainability 11, 1-21. https://doi.org/10.3390/su11051396

Marques, G.M., Augustine, S., Lika, K., Pecquerie, L., Domingos, T., Kooijman, S.A.L.M., 2018. The AmP project: Comparing species on the basis of dynamic energy budget parameters. PLOS Comput. Biol. 14, e1006100. https://doi.org/10.1371/journal.pcbi.1006100

Mendoza Beltran, A., Chiantore, M., Pecorino, D., Corner, R.A., Ferreira, J.G., Cò, R., Fanciulli, L., Guinée, J.B., 2018. Accounting for inventory data and methodological choice uncertainty in a comparative life cycle assessment: the case of integrated multi-trophic aquaculture in an offshore Mediterranean enterprise. Int. J. Life Cycle Assess. 23, $1063-1077$. https://doi.org/10.1007/s11367-017-1363-2

Mendoza Beltrán, A., Guinée, J., 2014. Goal and Scope Definition for Life Cycle Assessment of Integrated Multi-Trophic Marine Aquaculture Systems, in: Proceedings of the 9th International Conference on Life Cycle Assessment in the Agri-Food Sector (2014). pp. 817-822.

Mercier, A., Battaglene, S.C., Hamel, J.-F., 1999. Daily burrowing cycle and feeding activity of juvenile sea cucumbers Holothuria scabra in response to environmental factors. J. Exp. Mar. Bio. Ecol. 239, 125-156. https://doi.org/10.1016/S0022-0981(99)00034-9

Morgan, A.D., 2000. Aspects of the reproductive cycle of the sea cucumber Holothuria scabra (Echinodermata: Holothuroidea). Bull. Mar. Sci. 66, 47-57.

Namukose, M., Msuya, F., Ferse, S., Slater, M., Kunzmann, A., 2016. Growth performance of the sea cucumber Holothuria scabra and the seaweed Eucheuma denticulatum: integrated mariculture and effects on sediment organic characteristics. Aquac. Environ. Interact. 8, 179-189. https://doi.org/10.3354/aei00172

Nelson, E.J., MacDonald, B.A., Robinson, S.M.C., 2012. The absorption efficiency of the suspension-feeding sea cucumber, 
Cucumaria frondosa, and its potential as an extractive integrated multi-trophic aquaculture (IMTA) species. Aquaculture 370-371, 19-25. https://doi.org/10.1016/j.aquaculture.2012.09.029

Neofitou, N., Lolas, A., Ballios, I., Skordas, K., Tziantziou, L., Vafidis, D., 2019. Contribution of sea cucumber Holothuria tubulosa on organic load reduction from fish farming operation. Aquaculture 501, 97-103. https://doi.org/10.1016/J.AQUACULTURE.2018.10.071

Neori, A., Chopin, T., Troell, M., Buschmann, A.H., Kraemer, G.P., Halling, C., Shpigel, M., Yarish, C., 2004. Integrated aquaculture: rationale, evolution and state of the art emphasizing seaweed biofiltration in modern mariculture. Aquaculture 231, 361-391. https://doi.org/10.1016/j.aquaculture.2003.11.015

Orozco, Z.G.A., Sumbing, J.G., Lebata-Ramos, M.J.H., Watanabe, S., 2014. Apparent digestibility coefficient of nutrients from shrimp, mussel, diatom and seaweed by juvenile Holothuria scabra Jaeger. Aquac. Res. 45, 1153-1163. https://doi.org/10.1111/are.12058

Ozer, P.N., Mol, S., Varhk, C., 2004. Effect of the Handling Procedures on the Chemical Composition of Sea Cucumber. Turkish J. Fish. Aquat. Sci. 4, 71-74.

Paltzat, D.L., Pearce, C.M., Barnes, P.A., McKinley, R.S., 2008. Growth and production of California sea cucumbers (Parastichopus californicus Stimpson) co-cultured with suspended Pacific oysters (Crassostrea gigas Thunberg). Aquaculture 275, 124-137. https://doi.org/10.1016/J.AQUACULTURE.2007.12.014

Papatryphon, E., Petit, J., Kaushik, S.J., van der Werf, H.M.G., 2004. Environmental Impact Assessment of Salmonid Feeds Using Life Cycle Assessment (LCA). AMBIO A J. Hum. Environ. 33, 316-323. https://doi.org/10.1579/0044-744733.6.316

Papatryphon, E., Petit, J., Van Der Werf, H.M.G., Sadasivam, K.J., Claver, K., 2005. Nutrient-balance modeling as a tool for environmental management in aquaculture: The case of trout farming in France. Environ. Manage. 35, 161-174. https://doi.org/10.1007/s00267-004-4020-z

Parker, R., 2012. Review of life cycle assessment research on products derived from fisheries and aquaculture : A report for Seafish as part of the collective action to address greenhouse gas emissions in seafood. Final Rep. 24.

Pearson, T.H., Rosenberg, R., 1977. Pearson TH, Rosenberg R.. Macrobenthic succession in relation to organic enrichment and pollution of the marine environment. Oceanogr Mar Biol Ann Rev 16: 229-311. Oceanogr. Mar. Biol. 16.

Pelletier, N., Tyedmers, P., Sonesson, U.L.F., Scholz, A., Ziegler, F., Flysjo, A., Kruse, S., Cancino, B., Silverman, H., 2009. Not All Salmon Are Created Equal: Life Cycle Assessment (LCA) of Global Salmon Fanning Systems. Environ. Sci. Technol. $43,8730-8736$.

Pelletier, N.L., Ayer, N.W., Tyedmers, P.H., Kruse, S. a., Flysjo, A., Robillard, G., Ziegler, F., Scholz, A.J., Sonesson, U., 2007. Impact categories for life cycle assessment research of seafood production systems: Review and prospectus. Int. J. Life Cycle Assess. 12, 414-421. https://doi.org/10.1007/s11367-006-0275-3

Penina Tua Rahantoknam, S., 2017. Maturity Gonad Sea Cucumber Holothuria scabra Under The Month Cycle. IOP Conf. Ser. Earth Environ. Sci. 89, 12015. https://doi.org/10.1088/1755-1315/89/1/012015

Pete, R., Guyondet, T., Cesmat, L., Fiandrino, A., Bec, B., Richard, M., 2018. Projet CAPATHAU : CAPAcité trophique de la lagune de THAU. Livrable II. Description et évaluation du modèle GAMELag-Conch : modèle d'écosystème lagunaire exploité par la conchyliculture, adapté à la lagune de Thau.

Pitt, R., Duy, N., 2004. Breeding and rearing of the sea cucumber Holothuria scabra in Vietnam. In: Lovatelli A, Conand C, Purcell S, Uthicke S, Hamel JF, Mercier A (eds) Advances in sea cucumber aquaculture and management. FAO Fish Tech Pap 463. Rome.

Purcell, S., Conand, C., Uthicke, S., Byrne, M., 2016. Ecological roles of exploited sea cucumbers. Oceanogr. Mar. Biol. An Annu. Rev.

Purcell, S.W., 2014. Value, Market Preferences and Trade of Beche-De-Mer from Pacific Island Sea Cucumbers. PLoS One 9, e95075. https://doi.org/10.1371/journal.pone.0095075

Purcell, S.W., 2004. Criteria for release strategies and evaluating the restocking of sea cucumbers, in: FAO (Ed.), A Lovatelli, C Conand, SW Purcell, S Uthicke, JF Hamel \& A Mercier (Eds), Advances in Sea Cucumber Aquaculture and Management, FAO Fisheries and Aquaculture Technical Paper No. 463. Food and Agriculture Organization of the United Nations, Rome, pp. 181-191.

Purcell, S.W., Hair, C.A., Mills, D.J., 2012. Sea cucumber culture, farming and sea ranching in the tropics: Progress, problems and opportunities. Aquaculture 368-369, 68-81. https://doi.org/10.1016/j.aquaculture.2012.08.053

Purcell, S.W., Simutoga, M., 2008. Spatio-Temporal and Size-Dependent Variation in the Success of Releasing Cultured Sea Cucumbers in the Wild. Rev. Fish. Sci. 16, 204-214. https://doi.org/10.1080/10641260701686895

Purcell, S.W., Williamson, D.H., Ngaluafe, P., 2018. Chinese market prices of beche-de-mer : Implications for fisheries and 
aquaculture. Mar. Policy 91, 58-65. https://doi.org/10.1016/j.marpol.2018.02.005

Purwati, P., 2006. Reproductive Patterns of Holothuria Scabra (Echinodermata: Holothuroidea) in Indonesian Waters. Mar. Res. Indones. 30, 47-55. https://doi.org/10.14203/mri.v30i0.423

R Core Team, 2018. R: A language and environment for statistical computing.

Rasolofonirina, R., Vaitilington, D., Eeckhaut, I., Jangoux, M., 2005. Reproductive cycle of edible echinoderms from the SouthWestern Indian Ocean. II. The sandfish Holothuria scabra (Jaeger, 1833). West. Indian Ocean J. Mar. Sci. 4, 61-75. https://doi.org/10.4314/wiojms.v4i1.28474

Reid, G.K., Chopin, T., Robinson, S.M.C., Azevedo, P., Quinton, M., Belyea, E., 2013. Weight ratios of the kelps, Alaria esculenta and Saccharina latissima, required to sequester dissolved inorganic nutrients and supply oxygen for Atlantic salmon, Salmo salar, in Integrated Multi-Trophic Aquaculture systems. Aquaculture 408-409, 34-46. https://doi.org/10.1016/j.aquaculture.2013.05.004

Reid, G.K., Lefebvre, S., Filgueira, R., Robinson, S.M.C., Broch, O.J., Dumas, A., Chopin, T.B.R., 2018. Performance measures and models for open-water integrated multi-trophic aquaculture. Rev. Aquac. https://doi.org/10.1111/raq.12304

Reid, G.K., Liutkus, M., Robinson, S.M.C., Chopin, T.R., Blair, T., Lander, T., Mullen, J., Page, F., Moccia, R.D., 2009. A review of the biophysical properties of salmonid faeces: implications for aquaculture waste dispersal models and integrated multi-trophic aquaculture. Aquac. Res. 40, 257-273. https://doi.org/10.1111/j.1365-2109.2008.02065.x

Ren, J.S., Stenton-Dozey, J., Plew, D.R., Fang, J., Gall, M., 2012. An ecosystem model for optimising production in integrated multitrophic aquaculture systems. Ecol. Modell. 246, 34-46. https://doi.org/10.1016/j.ecolmodel.2012.07.020

Ren, Y., Dong, S., Qin, C., Wang, F., Tian, X., Gao, Q., 2012. Ecological effects of co-culturing sea cucumber Apostichopus japonicus (Selenka) with scallop Chlamys farreri in earthen ponds. Chinese J. Oceanol. Limnol. 30, 71-79. https://doi.org/10.1007/s00343-012-1038-6

Ren, Y., Dong, S., Wang, F., Gao, Q., Tian, X., Liu, F., 2010. Sedimentation and sediment characteristics in sea cucumber Apostichopus japonicus (Selenka) culture ponds. Aquac. Res. 42, 14-21. https://doi.org/10.1111/j.1365-2109.2010.02483.x

Riera, R., Pérez, Ó., Cromey, C., Rodríguez, M., Ramos, E., Álvarez, O., Domínguez, J., Monterroso, Ó., Tuya, F., 2017. MACAROMOD: A tool to model particulate waste dispersion and benthic impact from offshore sea-cage aquaculture in the Macaronesian region. Ecol. Modell. 361, 122-134. https://doi.org/10.1016/j.ecolmodel.2017.08.006

Robinson, G., Caldwell, G.S., Jones, C.L.W., Stead, S.M., 2019. The effect of resource quality on the growth of Holothuria scabra during aquaculture waste bioremediation. Aquaculture 499, 101-108. https://doi.org/10.1016/J.AQUACULTURE.2018.09.024

Robinson, G., Lovatelli, A., 2015. Global sea cucumber fisheries and aquaculture FAO's inputs over the past few years, FAO Aquaculture Newsletter 53. Rome.

Robinson, G., Pascal, B., 2011. Sea cucumber farming experiences in south-western Madagascar. ACIAR Proc. Ser.

Robinson, G., Slater, M.J., Jones, C.L.W., Stead, S.M., 2013. Role of sand as substrate and dietary component for juvenile sea cucumber Holothuria scabra. Aquaculture 392-395, 23-25. https://doi.org/10.1016/J.AQUACULTURE.2013.01.036

Robinson, S.M.C., Martin, J.D., Cooper, J.A., Lander, T.R., Reid, G.K., Powell, F., Griffin, R., 2011. The Role of Three Dimensional Habitats in the Establishment of Integrated Multi-Trophic Aquaculture (IMTA) Systems. Bull. Aquac. Assoc. Canada 109, 23-29.

Samuel-Fitwi, B., Wuertz, S., Schroeder, J.P., Schulz, C., 2012. Sustainability assessment tools to support aquaculture development. J. Clean. Prod. 32, 183-192. https://doi.org/10.1016/j.jclepro.2012.03.037

Sauvant, D., Ponter, A., Institut national de la recherche agronomique, Association Française de zootechnie, Institut National Agronomique, 2004. Tables of composition and nutritional value of feed materials: pigs, poultry, cattle, sheep, goats, rabbits, horses and fish. Wageningen Academic Publishers, The Netherlands. https://doi.org/10.3920/978-90-8686-668-7

Slater, M.J., Carton, A.G., 2009. Effect of sea cucumber (Australostichopus mollis) grazing on coastal sediments impacted by mussel farm deposition. Mar. Pollut. Bull. 58, 1123-1129. https://doi.org/10.1016/J.MARPOLBUL.2009.04.008

Slater, M.J., Carton, A.G., 2007. Survivorship and growth of the sea cucumber Australostichopus (Stichopus) mollis (Hutton 1872) in polyculture trials with green-lipped mussel farms. Aquaculture 272, 389-398. https://doi.org/10.1016/J.AQUACULTURE.2007.07.230

Soetaert, K., Petzoldt, T., Setzer, R.W., 2010. Solving Differential Equations in R: Package deSolve. J. Stat. Softw. 33, 1-25. https://doi.org/10.18637/jss.v033.i09

Strain, P.M., Hargrave, B.T., 2005. Salmon Aquaculture, Nutrient Fluxes and Ecosystem Processes in Southwestern New Brunswick, in: Hargrave, B. (Ed.), Environmental Effects of Marine Finfish Aquaculture, Handbook Environmental Chemistry. Springer-Verlag Berlin Heidelberg, New York, pp. 29-57. https://doi.org/10.1007/b136003 
Troell, M., Halling, C., Neori, A., Chopin, T., Buschmann, A.., Kautsky, N., Yarish, C., 2003. Integrated mariculture: asking the right questions. Aquaculture 226, 69-90. https://doi.org/10.1016/S0044-8486(03)00469-1

Troell, M., Joyce, A., Chopin, T., Neori, A., Buschmann, A.H., Fang, J.-G., 2009. Ecological engineering in aquaculture Potential for integrated multi-trophic aquaculture (IMTA) in marine offshore systems. Aquaculture 297, 1-9. https://doi.org/10.1016/j.aquaculture.2009.09.010

van der Meer, J., 2006. An introduction to Dynamic Energy Budget (DEB) models with special emphasis on parameter estimation. J. Sea Res. 56, 85-102. https://doi.org/10.1016/j.seares.2006.03.001

Wang, G., Dong, S., Tian, X., Gao, Q., Wang, F., Xu, K., 2015. Life cycle assessment of different sea cucumber (Apostichopus japonicus Selenka) farming systems. J. Ocean Univ. China 14, 1068-1074. https://doi.org/10.1007/s11802-015-2640-y

Watanabe, S., Kodama, M., Orozco, Z.G.A., Sumbing, J.G., Novilla, S.R.M., Lebata-Ramos, M.J.H., 2015. Estimation of energy budget of sea cucumber, Holothuria scabra, in integrated multi-trophic aquaculture., in: M. R. R. Romana-Eguia, F. D. Parado-Estepa, N. D. Salayo, \& M. J. H. Lebata-Ramos (Eds.), Resource Enhancement and Sustainable Aquaculture Practices in Southeast Asia: Challenges in Responsible Production of Aquatic Species: Proceedings of the Internation. Tigbauan, Iloilo, Philippines Aquaculture Department, Southeast Asian Fisheries Development Center, pp. $307-308$.

Watanabe, S., Kodama, M., Zarate, J.M., Lebata-Ramos, M.J.H., Nievales, M.F.J., 2012. Ability of sandfish (Holothuria scabra) to utilise organic matter in black tiger shrimp ponds, in: C. A. Hair, T. D. Pickering, \& D. J. Mills (Eds.), Asia-Pacific Tropical Sea Cucumber Aquaculture. Proceedings of an International Symposium Held in Noumea, New Caledonia, 15-17 February 2011 (ACIAR Proceedings No. 136) (Pp. 113-120). . ACT: Australian Centre for International Agricultural Research, Canberra.

Yokoyama, H., 2013. Growth and food source of the sea cucumber Apostichopus japonicus cultured below fish cages — Potential for integrated multi-trophic aquaculture. Aquaculture 372-375, 28-38. https://doi.org/10.1016/j.aquaculture.2012.10.022

Yokoyama, H., Tadokoro, D., Miura, M., 2013. Quantification of waste feed and fish faeces in sediments beneath yellowtail pens and possibility to reduce waste loading by co-culturing with sea cucumbers: an isotopic study. https://doi.org/10.1111/are.12247

Yu, Z., Hu, C., Zhou, Y., Li, H., Peng, P., 2012. Survival and growth of the sea cucumber Holothuria leucospilota Brandt: A comparison between suspended and bottom cultures in a subtropical fish farm during summer. Aquac. Res. 44, $114-124$. https://doi.org/10.1111/j.1365-2109.2011.03016.x

Yu, Z., Zhou, Y., Yang, H., Ma, Y., Hu, C., 2014. Survival, growth, food availability and assimilation efficiency of the sea cucumber Apostichopus japonicus bottom-cultured under a fish farm in southern China. Aquaculture 426-427, 238-248. https://doi.org/10.1016/j.aquaculture.2014.02.013

Yuan, X., Meng, L., Wang, L., Zhao, S., Li, H., 2016. Responses of scallop biodeposits to bioturbation by a deposit-feeder Apostichopus japonicus (Echinodermata: Holothuroidea): does the holothurian density matter? Aquac. Res. 47, 512-523. https://doi.org/10.1111/are.12511

Zamora, L.N., Yuan, X., Carton, A.G., Slater, M.J., 2018. Role of deposit-feeding sea cucumbers in integrated multitrophic aquaculture: progress, problems, potential and future challenges. Rev. Aquac. 10, 57-74. https://doi.org/10.1111/raq.12147

Zhang, J., Kitazawa, D., 2016. Assessing the bio-mitigation effect of integrated multi-trophic aquaculture on marine environment by a numerical approach. Mar. Pollut. Bull. 110, 484-492. https://doi.org/10.1016/J.MARPOLBUL.2016.06.005 


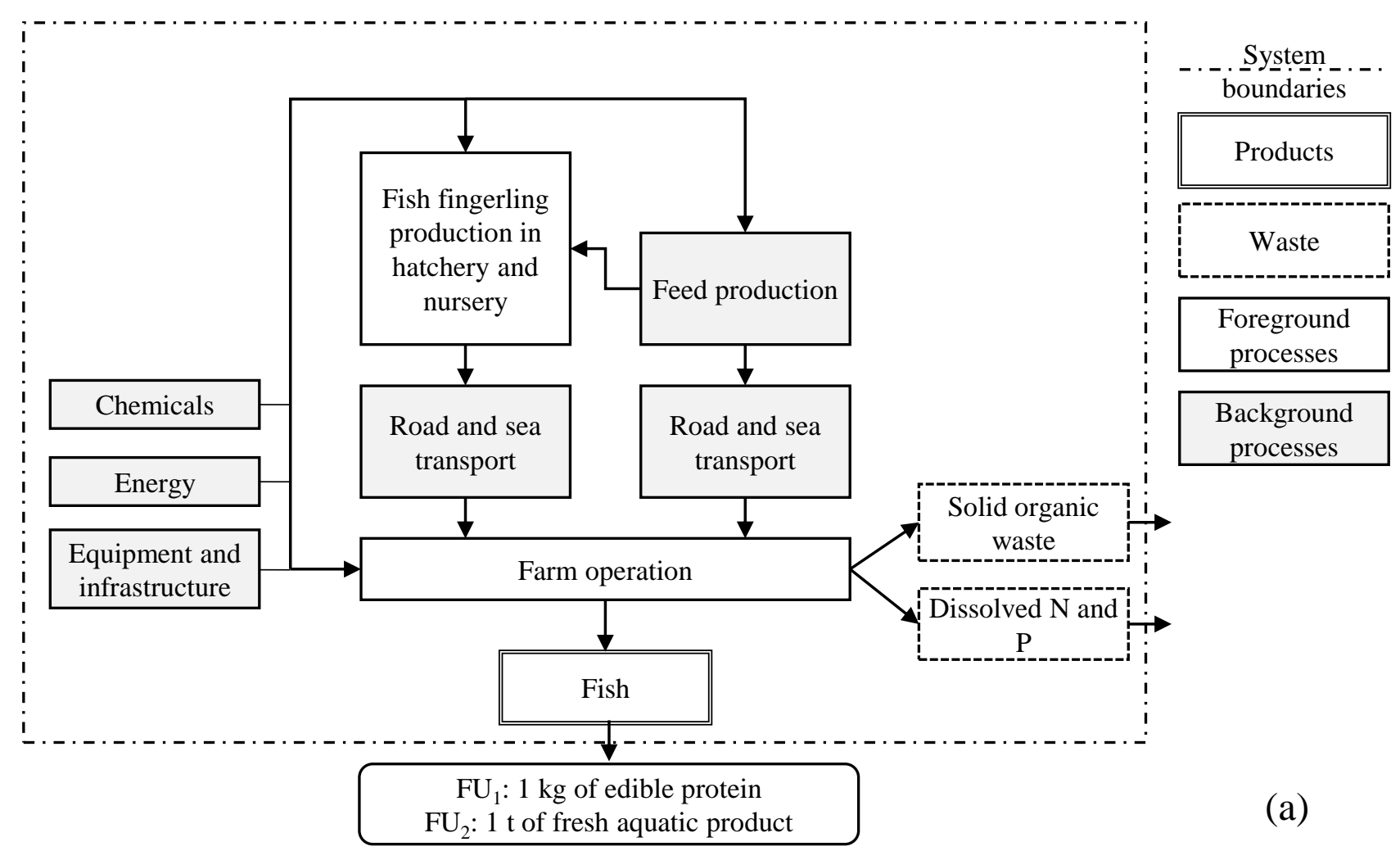




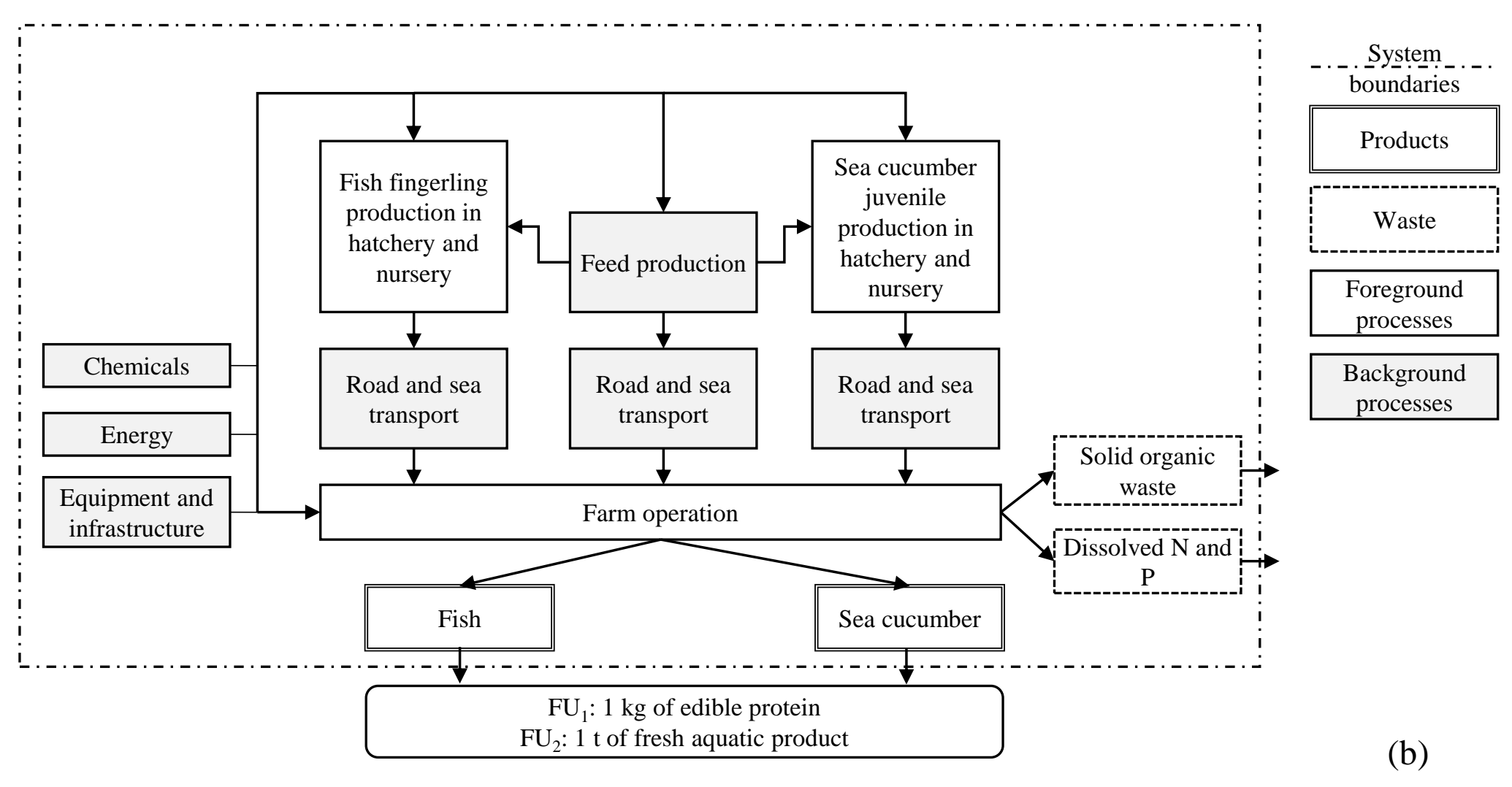


Finfish farm feces load

$120454 \mathrm{~kg}$ DW

(2862 kg N and $2246 \mathrm{~kg} \mathrm{P}$ )

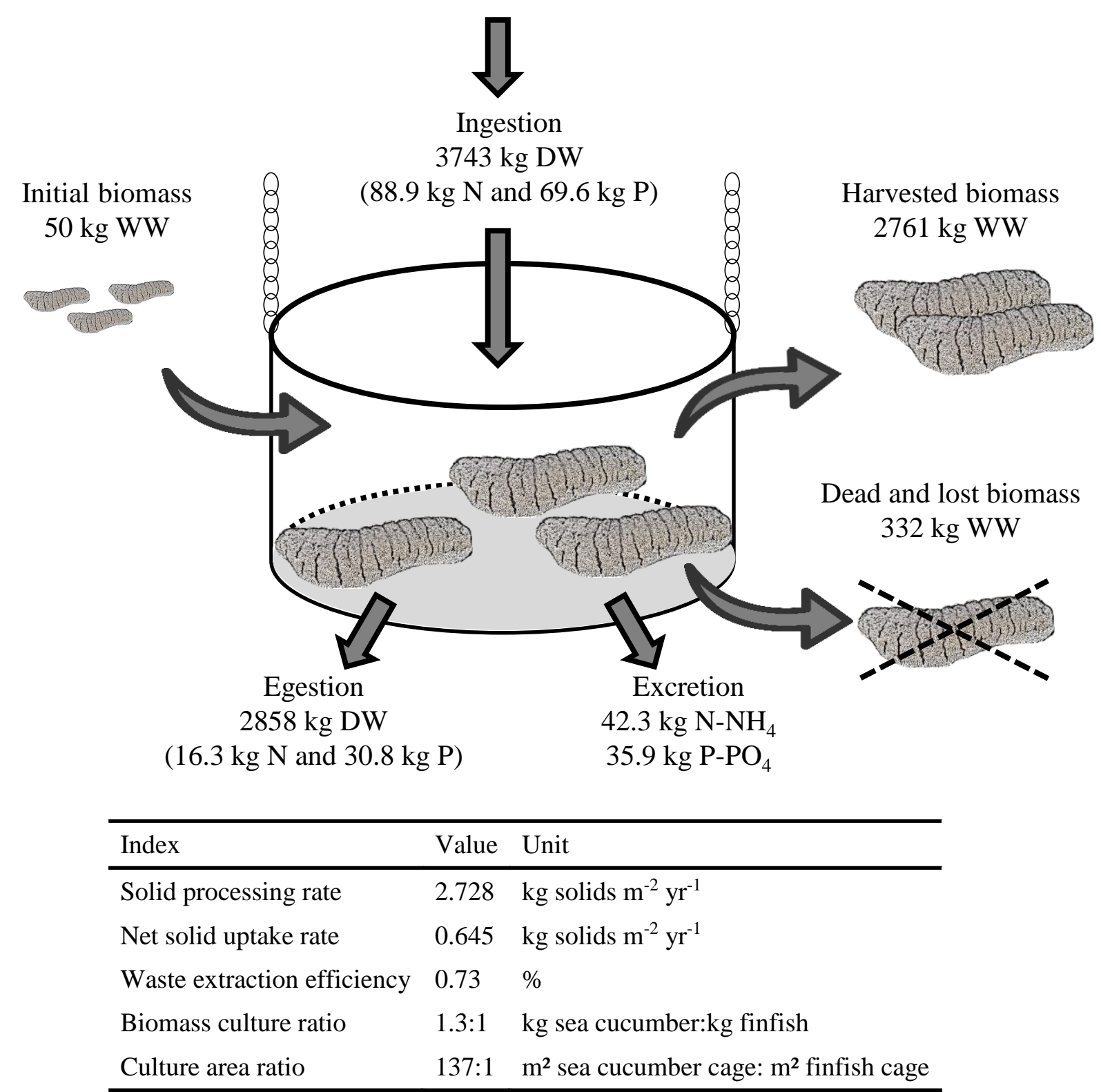


Impact per $\mathrm{kg}$ of edible protein

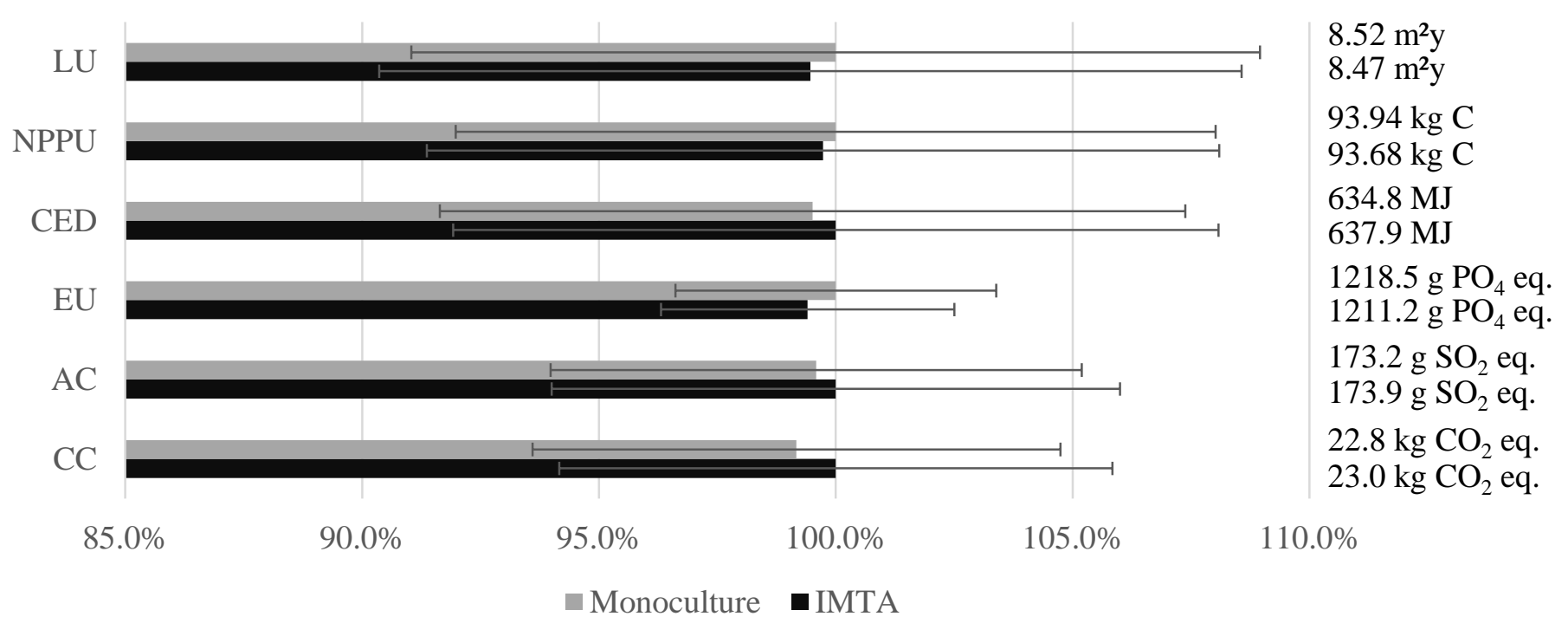

Impact per $t$ of fresh aquatic product

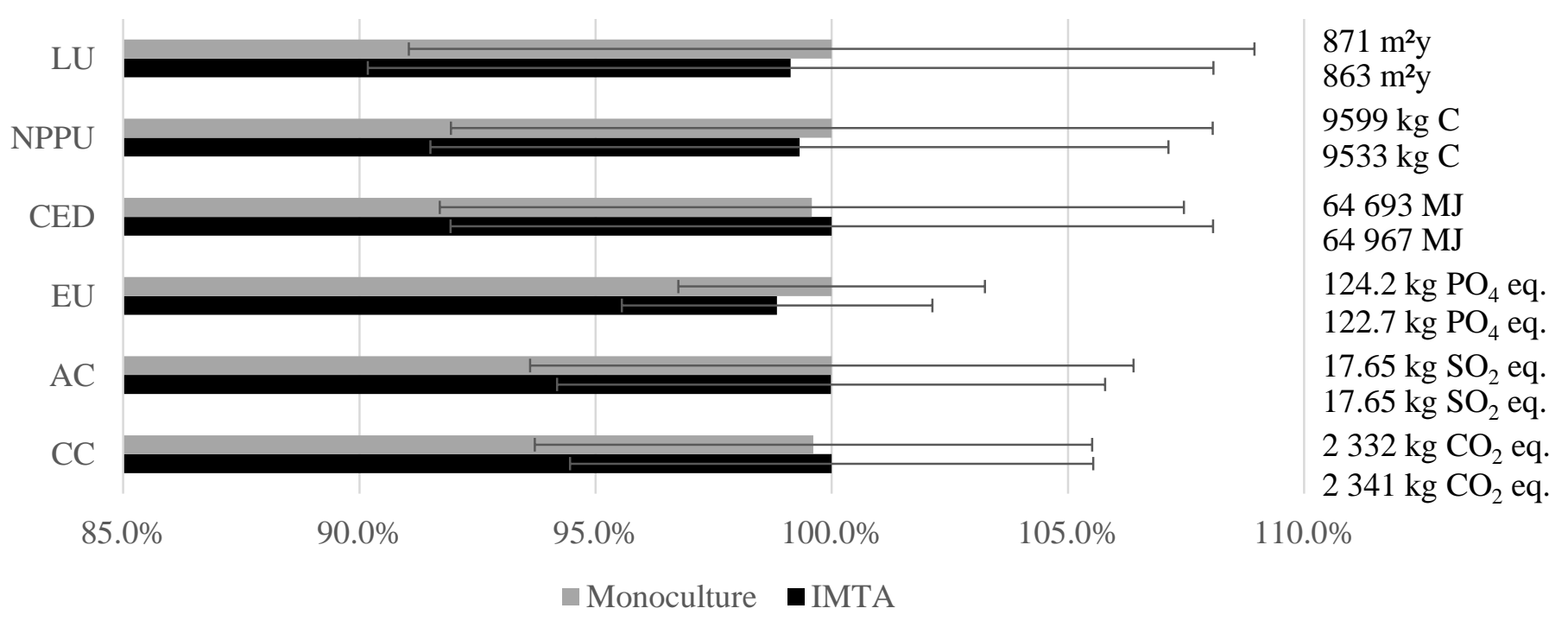

